BYLAAG TOT „KOERS” JULIE 1960.

\title{
DIE MISSIOLOGIE AS 'N TEOLOGIESE WETENSKAP
}

(Inougurele Rede gehou by die aanvaarding van die professoraat in die Sendingwetenskap aan die P.U. vir C.H.O. en Teologiese Skool, Potchefstroom op 17 Maart 1960, deur prof. H. du Plessis.)

\section{DIE ERKENNING VAN DIE MISSIOLOGIE.}

Die missiologie staan vandag in die teken van 'n reoriëntering wat betref die teologiese fundering daarvan, en daar is 'n groeiende consensus insake die noodsaaklikheid van ' $n$ fundamentele ,sendingteologie"1).

In aansluiting by die nuwere ontwikkelinge in hierdie opsig wil ons probeer aantoon wat onder die missiologie as 'n teologiese wetenskap verstaan moet word.

Hoewel die sending van die kerk byna 2,000 jaar oud is en die missiologiese literatuur al ' $n$ hele biblioteek $v^{2}{ }^{2}$ ), word die missiologie nog nie algemeen erken as 'n selfstandige teologiese wetenskap nie ${ }^{3}$. Maar dat in hierdie opsig alreeds baie gevorder is blyk daaruit dat daar in 1950 al een-en-sewentig leerstoele in die missiologie aan verskillende protestantse teologiese en universitêre inrigtings was. Die oorgrote meerderdheid hiervan, nl. 51 was egter versprei oor die Verenigde State van Amerika met net 13 op die vasteland van Europa en net een in Brittanje.")

In Engeland was die ontwikkeling meer in die rigting van integrasie, d.w.s. van alle teologiese professore word verwag om ook die missionêre aspek in hulle onderskeie vakke te behandel.')

Op grond daarvan dat elke teologiese vak 'n ,apostolaatsdimensie, 'n apostolaatsraamwerk en 'n apostolaatsgesigspunt" sou hẻ word integrering nou ook deur die apostolaatsteologie voorgestaan..$\left.^{\circ}\right)$

Desnieteenstaande is volgens Myklebust') die ontwikkeling in die praktyk meer in die rigting van aparte missiologiese leerstoele. Hieraan gee Myklebust self die voorkeur en hy noem verskillende gronde daarvoor.')

Tog word die missiologie nog geensins algemeen as 'n verpligte eksamenvak vir alle teologiese studente en dus ook as 'n volwaardige teologiese wetenskap beskou nie.') Hiermee kan volgens Myklebust geen genoeë geneem word nie. $\left.{ }^{10}\right)$

Maar die oortuiging wen veld dat nie alleen vanweë praktiese oorweginge nie maar veral vir die teologiese wetenskap self dit noodsaaklik is dat dit as ' $n$ volwaardige teologiese wetenskap erken moet word.") 
Dit is veral van belang vir Suid-Afrika, waar ons so nou en direk met die heidene en die jong kerke in kontak staan en ons predikante al meer in die sending die leiding moet gee, veral in plaaslike sendingaktiwiteite. ${ }^{12}$ )

\section{DIE TEOLOGIESE KARAKTER VAN DIE MISSIOLOGIE:}

\section{DIE VOORWERP EN PRINCIPIUM:}

Die belangrikheid en betekenis van die missiologie moet egter in die eerste plek gesien word in die teologiese karakter daarvan, maar veral in hierdie opsig is die teologie in sy betekenis verswak vanweë die subjektivistiese en relativistiese standpunt wat gedurende die $19 \mathrm{de}$ eeu teenoor die openbaring van God ingeneem is. ${ }^{33}$ )

Die voorwerp van die teologiese studie was nie meer die kennis van God soos geopenbaar in die Heilige Skrif nie, maar die menslike religie, en in die vergelykende godsdienswetenskap het die pseudoreligies soms 'n relatief hoër plek ingeneem as die Christelike. ${ }^{14}$ )

In die sending het hierdie noodlottige deformasie sy laagwatermerk so teen 1928 bereik, soos geblyk het op die tweede Internasionale Sendingkonferensie wat in hierdie jaar te Jerusalem gehou is. Hier is voorgestaan aanknoping by die "spiritual value" van die nie-Christelike religies. ${ }^{15}$ )

Die begin van 'n nuwe deurbraak tot ' $n$ meer teologiese uitgangspunt het egter gevolg toe uit die sogenoemde „Laymens' Report", Rethinking Messions") die gevaarlike van hierdie vergelykende metode duidelik aan die lig gekom het." ) In hierdie verslag kom voor 'n visie van die eenwording van die wêreld, waarin die verskillende religies mekaar sou leer verstaan en waardeer, waarin hulle mekaar sou laat deel in mekaar se geestelike ervarings en waarin hulle onderlinge relasie meer en meer sou word ,a common search for truth". Sending is nou nie meer evangelieprediking nie maar dit moet wees 'n uitwisseling van geestelike ervaringe, tot ' $n$ wedersydse beïnvloeding van mekaar en ' $n$ versterking van die geestelike broederskap. ${ }^{\text {s8 }}$ )

As gevolg van die reaksie in die sending hierteen en ook onder invloed van die nuwe teologie van $K$. Barth is weer uitgegaan van die openbaringstandpunt. ${ }^{19}$ ) Met al wat in hom is het Barth in sy religiebegrip hom gekeer teen die sintetiese tendens in die vergelykende godsdienswetenskap wat via Schleiermacher $^{20}$ ) en Troeltsch ${ }^{21}$ ) so 'n funeste invloed op die teologiese denke uitgeoefen het. Teenoor alle subjektivisme en relativisme in die religie stel hy 'n openbaringsuitgangspunt ${ }^{22}$ ), maar hierdie invloed van Barth op die protestantse sendingdenke is veral via $\mathrm{H}$. $\mathrm{Kraemer}^{23}$ ) uitgeoefen wat, hoewel hy nie in alles ' $n$ volgeling van Barth is nie, tog duidelik spore van Barthiaanse invloed in sy werke openbaar. ${ }^{24}$ ) Sy monumentale werk The Christian Message in a nonChristian world, ${ }^{25}$ ) wat hy as 'n studieverslag voorgelê het voor die derde 
Internasionale Sendingkonferensie wat in 1938 te Tambaran gehou is, het 'n groot invloed gehad op die besprekinge en besluite en dit het 'n hele omkeer in die sendingdenke teweeg gebring en nuwe vrae aan die orde gestel waaroor tot nou toe nog geen eenstemmigheid heers nie en waaroor daar telkens weer nuwe missiologiese verhandelinge verskyn. ${ }^{26}$ )

Volgens hom moet die nie-christelike religies gekonfronteer word met die openbaring van God in Christus. Hierdie standpunt het hy daarna in sy ewe klassieke werk Religion and Christian Faith"7) nader uitgewerk, en hy het probeer om dit hierin meer bybels te fundeer.

Uit hierdie konfrontering blyk volgens hom alleen maar diskontinuiteit tussen die openbaring en die menslike religie, maar in teenstelling met Barth sien hy die mens ook in sy religie, selfs die empiriese christelike religie, dialekties: die mens weet van God en soek Hom ook, maar in sy wete en soeke ontvlug hy ook God. Daar is wel aanknoping hierby moontlik, maar in die diep sin van die woord kan dit alleen in die antitese gevind word." )

Danksy die teosentriese religiebegrip van Barth is 'n teologiese diskussie oor die nie-christelike religies weer geopen ${ }^{29}$ ), en dit wil dus voorkom of in hierdie opsig weer ' $n$ basis gevind is vir die missiologie as 'n teologiese wetenskap, want terwyl dit in die teologie en dus ook in die missiologie gaan om die cognitio Dei $^{{ }^{30}}$ ) en sodanige cognitio alleen deur openbaring verkry kan word, moet uitgegaan word van die openbaring van God, maar dit het spoedig geblyk dat Barth se openbaringsbegrip nie bevredig nie.

So het Bavinck ${ }^{31}$ ) aangetoon dat Barth deur die verwaarlosing van die algemene openbaring en sy absolute antitese-standpunt nie die antwoord vind insake die aanknopingsvraagstuk nie. In aansluiting by Calvyn en op grond van noukeurige Skrifstudie veral van Rom. 1:18-32 kom Bavinck tot die konklusie dat die mens, selfs in sy gevalle toestand, nooit losgedink kan word van die algemene openbaring van God nie, maar ook dat die geadresseerde mens hierdie openbaring steeds verdring en vervang met sy eie religie. Daar is geen aanknoping by hierdie verdraaide waarheid moontlik nie, wel by die openbaring van God aan die mens.

Verder blyk uit Barth se eensydige aksentuering van die triomf van die genade dat hy sy antitetiese standpunt feitlik prysgee in sy uitverkiesingsleer, waarvolgens die triomf van die genade gesien moet word in die begenadiging van almal in Christus. ${ }^{32}$ ) Hiermee word die grens tussen kerk en wêreld feitlik uitgewis en die appellatiewe karakter van die kerugma word verswak tot ' $n$ blote mededeling van heilsfeite. ${ }^{33}$ )

Hierdie tendens kom ook aan die lig in die nuwere opvatting van die benadering deur kommunikasie ${ }^{34}$ ) wat, ten spyte van die waardevolle hierin, die gevaar inhou dat die solidariteit van die mensheid sò sterk geaksentueer word dat die oproep tot bekering verflou en selfs ontbreek, ${ }^{35}$ ) 
Die beslissende in bogenoemde en vir die teologie in die algemeen is die kardinale vraag wat onder openbaring verstaan word. En nou is dit by Barth en ook in die apostolaatsteologie en die meeste resente missiologiese werke duidelik dat die Woord van God hierin nie altyd erken word as die ten volle geinspireerde .gesagswoord van God en ook nie as die enigste voorwerp en principium cognoscendi van die teologie nie. Met hierdie ontkenning word die teologie in sy hart getref en kan daar nie sprake wees van 'n ware teologiese wetenskap waarin dit gaan om die kennis van God nie.

Dit kan alleen die geval wees indien as eerste vereiste gestel word die Heilige Skrif as die enigste objek ${ }^{36}$ ) en principium cognoscendi ${ }^{37}$ ) van die teologiese wetenskap en die erkenning van hierdie voorwerp en principium as die onfeilbare en ten volle geïnspireerde gesagswoord van God. ${ }^{38}$ )

\section{DIE TEOLOGIESE FUNDERING VAN DIE SENIDING.}

Maar vir die bepaling van die ensiklopediese plek en die betekenis van die missiologie as 'n teologiese wetenskap in die organisme van die teologiese wetenskap moet daar benewens hierdie algemene teologiese principium 'n teologiese uitgangspunt asook 'n eie principium divisionis ${ }^{39}$ ) vir die missiologie gevind word. Hiervoor is nodig dat nader ingegaan word op die teologiese fundering van die sending. So sal ook enigsins die omvang en belangrikheid van die missiologie aangetoon kan word.

\section{A. RESENTE ONTWIKKELINGE.}

Soos in geen ander teologiese wetenskap of kerklike werksaamheid nie, het die missionêre ontwikkeling van die afgelope drie dekades aan die lig gebring hoe noodlottig dit is as van die suiwere skrifbeginsels afgewyk word. ${ }^{40}$ )

Daardeur is die insig verkry dat hierdie noodlottige veral toegeskrywe moet word aan die skeiding van kerk en sending ${ }^{{ }^{1}}$ ) deur die genootskaplike sending en die kollegialistiese en piëtistiese kerkbegrip wat daarmee saamgegaan het." Hoofsaaklik as gevolg van hierdie skeiding was daar geen kerklike verband tussen ou en jong kerke nie, het die gevaar ontstaan van die algehele skeiding van die ou en jong kerke, was die sendingwerk hoofsaaklik beperk tot die werk van dic sendende organe, is die jong kerke nie geaktiveer tot sending nie, is hulle onder 'n voortdurende vongdy gehou, is ook die ou kerke nie geaktiveer tot sendingwerk en het die sendingleraar feitlik geen kerklike status gehad nie.

Die oë is hiervoor geopen veral na die onafhanklikwording van verskillende nie-westerse volke sedert die tweede wêreldoorlog, waarmee saamgeval het die selfstandigwording van die meeste jong kerke in die betrokke gebiede.

Kerke wat ooreenkomstig die tradisionele protestantse sendingdoelstelling van die drie "selves" van $H$. Venn ${ }^{43}$ ) en die pedagogiese sendingmetode van G. 
Warneck, ") die groot grondlêer van die protestantse sending en missiologie, op verre na nog nie selfstandig was nie, het nou eensklaps onafhanklik geword.

Terwyl ooreenkomstig hierdie doelstelling en beleid aangeneem is dat die sending se taak afgedoen is sodra 'n kerk selfstandig is, het hierdie jong kerke, wat in hierdie tradisie opgevoed is, dit ook as vanselfsprekend aanvaar dat hulle, nou dat hulle selfstandig geword het, geheel en al of grootliks ontslae is van enige verdere inmenging van die sending, veral waar die sending (,missions") en in besonder die genootskaplike sending, ${ }^{45}$ ) met sy administratiewe reëlende en regerende funksies, nie gesien is as die kerk van Christus nie maar grootliks as westerse voogde en instellinge. ${ }^{40}$ )

Hierdeur is kerk en sending voor baie ingewikkelde vrae geplaas en het die bestaansreg van die sending self in die gedrang gekom.") Dit het dus noodsaaklik geword dat ' $n$ diepere teologiese besinning oor die betekenis van die sending en kerk en hulle verhouding tot mekaar onderneem moes word.") Ook hierin is via $\mathrm{H}$. Kraemer en ander, Barthiaanse invloede te bespeur. ${ }^{48}$ )

Barth neem vir die nadere bepaling van die betekenis van die sending sy uitgangspunt in die ekklesiologie, wat volgens hom christologies gesentreer is. ${ }^{30}$ ) Nou word weer vir die eerste maal in dertig jaar in geskrifte en op sendingkonferensies weer gespreek van die kerk as die volk van die Here en die liggaam van Christus, van die geroepe ekklesia uit die wêreld, van die Heilige Gees as die derde Persoon in die Drieëenheid ens..")

In hierdie verband moet veral die naam van J. Dürr ${ }^{52}$ ) genoem word, wat die tradisionele sendingbeleid soos weerspieël in die werke van G. Warneck aan 'n deurtastende ondersoek onderwerp het. As uitgangspunt vir 'n teologiese missiologie neem hy 'n teologiese kerkbegrip wat volgens hom christologies is.

Die wese van die kerk is dat dit die liggaam van Christus is waarvan Christus die Hoof is en wat in Christus selfstandig staan. Die werklike selfstandigheid is "Christusständigkeit”.

Die pedagogiese metode van Warneck moet dus verwerp word, want 'n gemeente moet nie opgevoed word tot selfstandigheid nie maar is reeds in Christus selfstandig. Dit moet nie word wat dit nie is nie, maar wees wat dit in Christus is: „werde was du bist!"'s)

Die sending is van kerk tot kerk, en sendingvereniginge kan nie as sendende organe optree nie, en 'n ecclesiola in ecclesia is geen kerk nie.

Christus is volgens hom die eintlike Subjek van die sending, maar daarin handel Hy deur sy kerk. Net soos Barth is Dürr van gedagte dat saam met die christologiese die eskatologiese die twee konstituerende elemente is vir 'n reformatoriese kerkbegrip. ${ }^{54}$ )

Dit word nou algemeen aanvaar dat die skeiding tussen kerk en sending, soos dit voorgekom het in die genootskaplike sending en tot 'n mate ook in die kerklike sendingrade, moet verval. Sending moet kerksentries wees.55) 
Ook die Internasionale Sendingkonferensie wat in 1952 te Willingen ${ }^{56}$ ) gehou is, wil dat die sending van die kerk moet uitgaan: sending behoort tot die wese van die kerk, want daar is "no participation in Christ without participation in His mission to the world". ${ }^{57}$ ) Veral die verteenwoordigers van die jong kerke, wat self die skadelike van die skeiding van kerk en sending ondervind het, staan sterk daarop dat hierdie skeiding moet verval. ${ }^{59}$ ) Maar as reaksi ${ }^{59}$ ) teen die bloot kerksentriese sending is verder gestel dat die oorsprong nie in die kerk nie, maar trinitaries, ${ }^{10}$ ) en die einddoel ook nie in die kerk nie, maar in die basileia ${ }^{\text {s1 }}$ ) moet wees.

Insake die verhoudingsvraagstuk van ou en jong kerke is deur die Sendingkonferensie te Whitby (1947) as basiese formule gestel dat die sending die gesamentlike werk is van die ou en jong kerke en dat hulle hierin „partners in obedience" is, ${ }^{62}$ ) maar hierdeur is aan die jong kerke die inisiatief oorgelaat om te bepaal of en in hoeverre hulle die hulp van 'n ou kerk nodig het, en is die ou kerke in ' $n$ ondergeskikte posisie geplaas. ${ }^{63}$ ) Daarom is te Willingen probeer om deur 'n radikaal missionêr-ekumeniese siening hierdie dilemma op te los deur die teenstelling tussen jong en ou kerke te neutraliseer in die eenheid van die algemene kerk. Die sending is die voortdurende funksie van die algemene kerk, en elke groep christene is medeverantwoordelik vir die verkondiging van die Koningsheerskappy van Christus tot aan die uiterste eindes van die aarde..$^{64}$ )

Maar die stelling dat elke christengroep vir die ganse wêreldsending verantwoordelik is, is volgens Beyerhaus inkonkreet en hierdie ekumeniese siening van die universele kerk is volgens hom "geschichtslos", want op die agtergrond van die bestrede onderskeiding van jong en ou kerke staan tog enersyds onbetwisbare genealogiese betrekkinge en andersyds verskillende stadiums van geestelike ontwikkeling. $\left.{ }^{65}\right)$ Die sending is tog nie net heroutdiens in die wêreld nie, maar ook die versterking van die jong kerke wat nog baie tekort kom. (1 Tess. $3: 2,10){ }^{66}$ )

\section{B. FUNI)ERING.}

Op die lclank af word in bogenoemde grootliks weer suiwer skriftuurlike geluide gehoor. So kan dit aanvaar word dat vir die fundering van die sending eers die suiwere kerkbegrip bepaal moet word asook dat daarvoor die christologiese en eskatologiese twee konstituerende momente is. ${ }^{67}$ ) Voorts word die oorsprong van die sending tereg in die Triniteit geplaas. Maar aangesien die sending ' $n$ kerklike saak is en die kerk self in die Triniteit gefundeer is, sou ons vir die fundering van die sending benewens die eskatologiese en christologiese die trinitariese as hoofmomente vir 'n suiwere kerkbegrip wil stel.

Hieroor sal daar wel 'n groot mate van eenstemmigheid gevind word, maar dit wil nog nie gê dat daar dieselfde consensus insake die betekenis van die 
inhoud van die terme is nie. Daarom is dit bo alles nodig dat daar duidelikheid is oor die presiese konnotasie en strekking van die gebesigde woorde.

(i) Die Trinitariese Fundering:

Voorop moet gestel word die trinitariese fundering as uitgangspunt. Die teologie en dus ook die missiologie kan alleen deurgaan vir 'n teologiese wetenskap as dit in respectu Dei gesien word met 'n teologiese uitgangspunt, en in die plasing van die oorsprong van die kerk en dus ook die sending in die Triniteit het ons dus soos dit voorkom so 'n teologiese fundering.

Maar waarlik teologies is dit alleen as die oorsprong en fundering nie geplaas word in die werk van die Triniteit in die geskiedenis nie ${ }^{6 b}$ ) maar soos Kuyper dit stel in die ewige Raad van $\operatorname{God}^{60}$ ) of in die ewige besluit en wil van God, soos Voetius aangee. ${ }^{70}$ )

Die inhoud van die Raad van God kan kortliks omskrywe word as die ewige voorneme van die Triniteit tot die rekapitulasie van die bewuste sowel as die onbewuste kreatuurlike en die oorwinning en veroordeling van die satan en sy ryk. In die Raad van God is ook opgeneem al die weë en middele vir die verwerkliking van hierdie doel. ${ }^{71}$ ) (Ef. 1:11, Jes. 46:10).

Wat hiervan in ons menslike voorstelling stuksgewys in die geskiedenis gerealiseer word is egter in die Raad van God 'n grootse ewigheidsomspannende eenheid en reeds van ewigheid af 'n wesenlike werklikheid, en wat daarvan in ons voorstelling verwerklik word is slegs die uitvloeisels van wat reeds by God ' $n$ wesenlike werklikheid is. ${ }^{2}$ )

Van hierdie uitgangspunt gesien word duiselingwekkende wye en grootse perspektiewe geopen wat die ganse kosmos, alle tye tot in ewigheid omvang.

Alleen in hierdie lig is daar sin en betekenis in die geskiedenis, 'n vaste gang deur die eeue en 'n ontwyfelbare sekerheid oor die uiteindelike afloop van die wêreldgebeure. Alleen met hierdie uitgangspunt kan deurgedring word tot die betekenis en wese van die kerk en sending.

Aangesien hierdie rekapitulasie alleen kan gerealiseer word as God versoen is met die mens, wat die beeld van God is en bestem is om die koningsepter oor die wêreld te hanteer, is Christus van ewigheid af verkies (Ef. 1:4) tot die Middelaar") (Ef. 1:5-7) en Hoof ${ }^{74}$ ) (Ef. 1:10, 22) van die bewuste en onbewuste kreatuur, sodat alles in en onder Hom tot vervulling (die volheid, pleroma) en die bestemde doel kan kom (Ef. 1:10, 22, 23; Kol. 1:19).

So is Christus die uitverkore Kneg van die Here (Jes. 52:13 e.v.) deur wie God ons met Homself versoen ( 2 Kor. 5:18), en die groot liefde maar ook die groot heerlikheid van die Seun word daarin openbaar dat $\mathrm{Hy}$ in die ewige pactum salutis van die Drieëenheid Hom vrywillig onderwerp het om so in dienskneggestalte en as die Man van Smarte op te tree. ${ }^{73}$ )

Maar dit wil nie sê dat die verkiesing gefundeer is in Christus nie. Dit is gegrond in die wil en besluit van die Drieënige God wat na sy welbehae en in 
sy liefde sy skepping nie loslaat nie; ${ }^{76}$ ) maar omdat die mensheid nie sonder Christus verlos kan word nie, is in en saam met Christus ook van ewigheid af verkies sy gemeente (Ef. 1:4) en kan ook Hy nie losgedink word van hierdie gemeente van Hom nie. ${ }^{77}$ )

Sy gemeente is in Hom verkies as 'n organiese geheel, as die nuwe mensheid wat deur sy versoeningswerk verlos word uit die ewige dood en die mag van die duiwel. Dit is sy ekklesia wat bestaan uit alle uitverkorenes van alle tye en alle volke. Hoewel dit nie atomisties verkies word as 'n turba electorum nie (Calvyn) maar as 'n eenheid en organiese geheel, ${ }^{78}$ ) vorm hierdie een nuwe mensheid tog in die ewige Raad van God 'n numerus clausus en is die nieuitverkorenes die droë takke van die boom ${ }^{79}$ ) (Rom. 8:29-30), 9:22).

(ii) Die Christologiese.

(1) Die wese van die Kerk.

Uit die uitverkiesing van die kerk van die Here in Christus volg in die eerste plek die christologiese karakter van die kerk as die wese daarvan. Dit moet egter nie soos $\mathrm{K}$. Barth doen in Christomonistiese sin opgevat word dat Christus naamlik die grond en subjek van die uitverkiesing is nie, ${ }^{\prime 0}$ ) maar dat Christus die spieël ${ }^{11}$ ) daarvan is en die kerk in Christus die uitvloeisel van die Raad van God $^{\text {22 }) ~ e n ~ d i e ~ v r u g ~ v a n ~ d i e ~ v e r k i e s i n g ~ i s . ~}{ }^{83}$ )

Die kerk is die gemeente wat in Christus tot die ewige lewe uitverkies is, en vir die openbaring van hierdie gemeente moet die uitverkorenes byeenvergader word in die sigbare geïnstitueerde ekklesia ${ }^{84}$ ) wat as 'n afstraling van die kerk in die Raad van God $^{35}$ ) die vergadering van die ware gelowiges moet wees. ${ }^{\text {s6 }}$ )

(2) Die Waarheid.

In die tweede plek volg uit die uitverkiesing in Christus dat die kerk gebind is aan die waarheid en daarop gefundeer is, want ook hierin moet dit 'n afstraling wees van die kerk in die Raad van God, en omdat dit in Christus uitverkies is en in Christus bestaan en Christus self die waarheid is (Joh. 14:6), is dit ook met Christus in die waarheid verbind. ${ }^{\text {"7 }}$ )

(3) Die Missionêre.

Uit die wese van die kerk as christologiese gemeente volg verder dat dit ook in Christus verkies is tot sendingdiens in die wêreld, want kragtens die pactum salutis word Christus as Middelaar gestuur om die versoeningswerk te volbring en sy uitverkorenes byeen te vergader en te bewaar" ${ }^{\text {"l }}$ ) en is $\mathrm{Hy}$ as Kneg van die Here verkies tot die lig van die nasies (Jes. 49:6), en omdat sy gemeente met Hom in die sendingdiens tot die byeenvergadering van sy uitverkorenes verbind is en hierdie diens ' $n$ afskaduwing en voortsetting is van sy diens, ${ }^{89}$ ) sê Hy aan sy apostels en daarmee aan sy kerk: soos die Vader My gestuur het, stuur Ek ook julle (Joh. 20:21, vgl. Jos. 17:18). 
Vir hierdie diens is die volk van God in Christus gepredestineer en uitverkies. Hoewel die uitverkiesing nie beperk kan word tot diens alleen nie en met en in hierdie diens ook die individuele saligheid ingesluit is, ${ }^{\circ 0}$ ) is die laaste nie die hoofsaak nie. ${ }^{91}$ ) Die aksent moet gelê word op hierdie uitverkiesing tot diens, waarvan die sendingdiens 'n belangrike aspek is (1 Pet. 2:9).

Die feit dat hierdie sendingdiens nie 'n bykomende opdrag in die tyd is nie maar gegrond is in die ewige besluit van God, is daarvoor ' $n$ kragtige stimulus en motief en verleen daaraan 'n verheffende betekenis, en deur die geloof daaraan kom daar 'n rustige en versekerde gang in die sendingwerksaamhede..$^{92}$ )

(4) Die Amptelike.

'n Verdere konsekwensie wat uit die christologiese karakter van die kerk as die kerk wat in Christus verkies is, voortvloei is die amptelike karakter van die sendingarbeid, want Christus is amptelik verkies tot Middelaar, tot Kneg van die Here en is daarvoor amptelik gesalf, en so is $\mathbf{H y}$ die Christus.") Daarvoor ontvang $\mathrm{Hy}$ ook as verhoogde Here alle volmag (Matt. 28:18) en daarom stel $\mathrm{Hy}$ in en vir die uitoefening van hierdie volmag sy kerk in amptelike sendingdiens. ${ }^{44}$ )

Vir die fundering van die kerk op die warheid en die uitoefening van die diakonia van die kerk laat Christus sy kerk die gestalte aanneem van die apostoliese kerk." )

Omdat die unieke betekenis van die apostels soos die naam self aandui,") was dat hulle gevolmagtigdes was, is die apostolisiteit van die kerk primêr") en ontvang die kerklike diakonia as amptelike diens 'n besondere aksent.

Maar aangesien die apostels ook uitgesondenes was, is ook die sendingroeping op die kerk gelê, ${ }^{\text {px }}$ ) maar terwyl hulle as gevolmagtigdes uitgestuur word is die sending kerklike werk, amptelike diens, hoewel nie met dieselfde

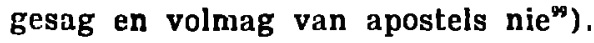

Aangesien die kerk in Christus uitverkies is en dit niks sonder Christus is nie, en terwyl Christus die groot Apostel is van die Vader, word die kerk in en met Christus verbind deur die uitstorting van die Heilige Gees en word die kerk so bekwaam en gewillig gemaak vir hierdie missionêre roeping en word dit die kerk van die getuienis, ${ }^{100}$ ) deur wie Christus as die eintlike Subjek van die sending getuig en predik. So is die sending van die kerk missio Dei. ${ }^{\text {(1) })}$

Sendingwerk moet dus gekarakteriseer word as kerklike arbeid waarvoor die kerk amptelik in diens gestel is. ${ }^{103}$ ) Die teologiese fundering van die sending is dus christologies in die sin dat die kerk, wat in Christus uitverkies is, in Hom gepredestineer is om amptelik in die diaconia Christi na alle volke uitgestuur te word, vir watter diens dit die Heilige Gees ontvang wat hierdie 
sendingarbeid deur die kerk uitvoer. Sending is dus amptelik in die hoë sin van die woord.

Hieruit volg egter nie dat die sendingtaak beperk is tot die offisiële instansies van missionêre leraars, sendingkommissies, deputate ens. nie, want hoewel die ampsdraers gemagtigdes is van Christus en nie van die gemeente $n i e,{ }^{103}$ ) is die sendingtaak aan die gemeente opgedra en is die hele gemeente daarvoor verantwoordelik (1 Pet. 2:9). Hierdie opdrag aan die gemeente word wel in die ampsdraers uitgewerk, maar hulle word deur die gemeente aangewys en is ook in diens van die gemeente en hulle ageer in noue kontak en verband met die gemeente. As christologiese gemeente het die hele gemeente deel aan die sending, en elke lidmaat het as staande in die amp van die gelowige mede ' $n$ roeping om die deugde van die Here te verkondig (1 Pet. 2:9). ${ }^{104}$ )

Uit die kerklike karakter van die sending kan nou die volgende belangrike gevolgtrekkinge gemaak word:

(a) 'n Sendingleraar beklee as ampsdraer 'n kerklike amp en is 'n gewone bedienaar van die Woord wat vir sendingwerk afgesonder word..$^{105}$ )

(b) Aangesien in die allereerste plek die plaaslike gemeente die openbaring is van die liggaam van Christus, aan wie die bediening van Woord en sakramente en die uitoefening van die sleutelmag toevertrou is, is die sendende orgaan die plaaslike gemeente. ${ }^{106}$ ) So is die sending eers kerklike arbeid waarby die hele kerk betrek is.

(c) Daarom moet die sendeling die leraar wees van die gemeente wat hom uitstuur ${ }^{107}$ ) vir die kerklike werk van verkondiging, planting van gemeentes en om te leer alles wat Christus beveel het om te onderhou (Matt. 28:19).

(d) Die verband tussen ou en jong kerke moet kerklik wees, maar dan nie van twee verskillende uiteenlopende kerke nie maar van kerke wat die pluriforme openbaringe van die een kerk van Christus is, wat gegrondves is op dieselfde skriftuurlike waarheid, hoewel met eiesoortige nuanseringe. Die ou en jong Gereformeerde kerke is dus aan mekaar verbind en is in wese een Gereformeerde kerk, hoewel daar 'n pluriforme openbaring van die een kerk is. ${ }^{108}$ )

Vanweë die kerklike karakter van die sending en die kerklike eenheidsband staan die jong kerke nie teenoor vir hulle vreemde westerse instellinge en 'n vreemde sending nie, soos dit die geval is in die onkerklike sending, maar saam met die ou kerke in die verband van die een kerk van Christus waaraan hulle self verbind is. ${ }^{109}$ )

As die samewerking insake die sendingwerk van die jong en ou kerke in hierdie eenheidsband verder kerklik gereël word, verval baie van die moeilikhede wat die onkerklike sending meebring. Die samewerking moet met onderlinge oorleg tussen die betrokke kerke op kerklike wyse gereël word 
en die eintlike eenheidsband moet veral op intersinodale vlak tot openbaring kom. ${ }^{10}$ )

Hieruit volg egter nie dat die ou kerk geweer kan word uit noodsaaklike sendingwerk in die ressort van die jong gemeentes en ook nie dat die jong kerke ipso facto en summier ontslae is van alle toesig van die ou kerk nie."11)

Alles moet op kerklike wyse gereël word tot openbaring van die kerk van Christus wat self so sy amptelike volmag en diens vervul.

Hoewel daar ten spyte van die reaksie teen kerklike sending vandag byna algemeen toegegee word dat die sending kerklik moet wees, ${ }^{12}$ ) en daar ook goeie Nuwe Testamentiese gronde hiervoor en vir die plaaslike gemeente as sendende orgaan en vir kerklike samewerking en verband tussen ou en jong kerke is,"') gaan die sending in die praktyk nog hoofsaaklik uit van sendinggenootskappe $^{114}$ ) of, waar dit kerklik is, ooreenkomstig die kollegialistiese kerkbegrip, van meerdere vergaderings, en daar word selfs voorgestaan dat ekumeniese rade in sekere gevalle as sendende organe kan optree. ${ }^{115}$ )

Solank dit so is en die oog hoofsaaklik gerig word op ekumeniese samewerking van die een universele kerk-instituut, wat nie bestaan nie, kan 'n kerklike verband nie gelê word nie en sal kerk en sending grootliks van mekaar geskei bly.

(5) Sending en die apostolisiteit, heiligheid, eenheid en katolisiteit van die kerk.

Vir die bepaling van die betekenis van die sending en die missiologie is dit verder nodig dat die sending ook in relasie tot die apostolisiteit, eenheid, heiligheid en katolisiteit van die kerk gesien word.

Ook die heiligheid, eenheid en katolisiteit van die kerk het alleen wesenlike betekenis as dit in die ewigheidslig van die Raad van God gestel word. Daarin is dit ' $n$ wesenlike, werklike en vaste heiligheid, eenheid en katolisiteit van die kerk van Christus wat in Hom uitverkies is."16) Wat in die ewige Raad van God 'n wesenlike werklikheid het, word geopenbaar in die verhoogde Christus in wie die eienskappe objektief verwerklik is. ${ }^{17}$ )

Hierdie eienskappe moet dus nie nog verkry word nie. Dit is reeds wesenlike werklikhede, maar wat die kerk so in dic Raad van God is en in Christus is en besit, moet ook afgestraal word in die lewe van die kerk, en hoewel daarvan op aarde nooit 'n adekwate uitdrukking verwesenlik kan word nie, moet iets daarvan tog gesien word in die lewe en belydenis van die gelowiges, maar ook in die kerk as instituut moet die liggaam van Christus geopenbaar word en moet daar 'n afspieëling en weerkaatsing van die heerlikheid in Christus wees, en in elke gemeente moet tot openbaring kom die een heilige algemene kerk van Christus. ${ }^{118}$ )

In hierdie omlysting val daar nuwe lig op die missionêre aspek van hierdie drie eienskappe asook op die apostolisiteit van die kerk. Wat die 
laaste betref moet dit as wins beskou word dat nou aanvaar word dat in die begrip apostoliese kerk nie net die apostolisiteit nie maar ook die ,apostolaat" opgesluit lê. $\left.{ }^{119}\right)$ Maar dan moet die eerste as die primêre ${ }^{120}$ ) gesien word, want van 'n kerk wat nie gefundeer is op die waarheid nie kan daar geen ware lewe en ook geen ware sending uitgaan nie. Die kerk as belydenis- en belydende kerk ${ }^{12 !}$ ) moet die waarheid bely en daarvan getuig, omdat dit die waarheid in Christus besit. Daarom moet sending sonder apostolisiteit uiteindelik doodloop, maar aan die ander kant is dit net so waar dat handhawing van die belydenis sonder sending tot koue, dooie konfessionalisme lei. ${ }^{122}$ )

Sending en Eenheid.

Die eenheid in Christus wat ook tot openbaring moet kom in die kerk van Christus verkry in die huidige sending-situasie ' $n$ besondere aktualiteit ${ }^{13}$ ), veral vir die jong kerke wat as swak en klein minderhede teenoor dieselfde heidendom en ongeloofsmagte die vorming van 'n kerklike eenheidsfront daarteenoor as 'n noodsaaklikheid beskou en die versplintering van die Protestantisme in so baie sektes en kerke betreur. ${ }^{124}$ ) Vanuit hierdie sendingsituasie word die eenheidsvraagstuk in al sy konkrete aktualiteit en dringendheid voor die aandag van die ,sendende" kerke gestel ${ }^{125}$ ) wat mekaar soms op dieselfde sendingveld bestry.

Maar Christus self het ook sending en eenheid met mekaar verbind en gebid dat daar eenheid mag wees ,sodat die wêreld kan glo dat U My gestuur het" (Joh. 17:21). Christus bid dus vir eenheid met die oog op die sending, "unity for the road". ${ }^{126}$ )

Hoewel Christus hier nie bid $^{127}$ ) dat daar een kerk op aarde moet wees nie, lê in sy gebed tog opgesluit 'n bede vir die openbaring van die eenheid ook in die instituut.

Maar nou word op grond van die verband wat Christus tussen eenheid en sending gelê het, gepleit vir kerklike eenheid selfs met geloofsverdeeldheid, ${ }^{126}$ ) maar Christus verbind hier nie net eenheid en sending met mekaar nie maar 'n trits van eenheid, sending en waarheid en laat die laaste blykens die verband vooropgaan: Jesus spreek in vs. 18 van sy dissipels wat as apostels (gevolmagtigdes) gestuur word soos $\mathrm{Hy}$ deur die Vader as Apostel (gevolmagtigde) gestuur is (vgl. Joh. 20:21-23), en sodat hulle in staat gestel kan word om hierdie taak te vervul, bid $\mathrm{Hy}$ dat hulle geheilig mag word in die waarheid wat die Woord van God is (vs. 17).

Die enigste gevolgtrekking is dus dat die cenheid op die waarheid gebaseer moet wees. Dit volg ook vanselfsprekend uit die christologiese karakter van die kerk, want daar is geen gemeenskap met Christus moontlik buite die waarheid nie, want Hyself is die waarheid (Joh. 14:6). In hierdie trits moet die apostolaat sowel as die eenheid gebaseer wees op die apostolisiteit van die kerk. Dan alleen is daar ware eenheid en 'n lewende sendingbesef. 
Daarom is dit van primêre betekenis dat die kerk opgebou word in die geloof en gelei word in alle waarheid.

Dit ontslaan die kerk egter nie van die plig om die eenheid in Christus ook tot openbaring te bring en dit ook te soek selfs buite die eie kerklike verband nie. Die noodlottige kerklike verdeeldheid en verskeuring veral op die sendingveld is ook ' $n$ skande vir die kerk, en die Here spreek ook hierdeur en deur die duidelike merkbare eenwording van die mensheid en die wêreld, die ontsettende ontkerstening van die Weste asook deur die ekumeniese beweging self tot ons om die eenheid in Hom, met handhawing van die waarheid, ook te openbaar en te soek, ook buite die eie kerklike verband.

Nou is dit baie jammer dat die Gereformeerde kerke deur die onbevredigende sogenoemde gespreksbasis van die Wêreldraad van kerke van deelname daaraan uitgesluit word, ${ }^{129}$ ) maar dit verdien tog oorweging of by wyse van die afvaardiging van waarnemers nie 'n aanraking hiermee moet plaasvind nie, Sending en die Heiligheid van die Kerk.

Die eenheid en universaliteit van die kerk moet nie alleen gesien word in relasie tot die "apostolaat” en die apostolisiteit van die kerk nie, maar ook tot die heiligheid daarvan, want in Christus is dit nie net die een en die universele en apostoliese sendingkerk nie, maar ook die heilige gemeente.

Die kerk van Christus is in Christus as 'n heilige gemeente uitverkies en is van hemelse oorsprong en is gerig op die werklikheid in Christus. Op grond van sy ewige oorsprong is dit in Christus 'n heilige gemeente wat sui generis is, en kan dit nie vereenselwig word met kulturele en nasionale aspirasies nie, en daarom kan volk of ras ook nie konstitutief wees vir die kerk nie ${ }^{130}$ ) en kan ook nie gespreek word van 'n volkskerk nie.'") Die kerk van Christus beantwoord aan sy roeping alleen as dit antiteties staan teenoor die leuen.

Heiligheid en Katolisiteit.

Maar terwyl die volk van God nie atomisties verkies is nie maar as die nuwe mensheid in Christus, moet die kerk ook totalitêr gerig wees op hierdie universaliteit. Ook die heiligheid het dus 'n universele gerigtheid, daarbenewens is die kerk die een heilige gemeente van Christus wat geheilig is in die waarheid. Dit is saam met Christus aan die kant van God gestel ook vir die werksaamheid van God tot die byeenvergadering van sy uitverkorenes.

In hierdie verband ontvang die universele betekenis van die uitverkiesing en verbond ' $n$ besondere aksent ${ }^{132}$ ) daarin dat dit nie in die eerste plek gerig is op 'n eksklusiewe groep mense wat van die wêreld geisoleer word nie, maar dat beide universele strekking het en die hele mensheid, die volle pleroma van die liggaam van Christus op die oog het.

So is die verbond met Abraham gesluit dat in hom alle geslagte geseën word (Gen. 12:3) en is Israel verkies om ' $n$ lig vir die nasies te wees en is ook 
Christus as die Kneg daarvoor verkies, en so is $\mathrm{Hy}$ ook inderdaad die lig en die waarheid en is sy volk in Hom verkies om die deugde van God te verkandig.

Hierteenoor word egter gestel dat die kerk vanweë sy missionêre gerigtheid op die wêreld solidêr daarmee moet wees. ${ }^{133}$ ) Die wese van die kerk is hierdie apostolaat en die kerk is in die wêreld, ${ }^{134}$ ) en in Christus is daar begenadiging vir almal. ${ }^{135}$ ) Hierdeur word die identiteit en die antitetiese karakter van die kerk egter prysgegee en word dit 'n gewone sosiologiese verskynsel.

Maar uit die heiligheid van die kerk volg nie dat solidariteit van die kerk met die wêreld in sy nood en ellende daardeur uitgesluit word nie.

Die teologiese fundering van die solidariteit is egter nie geleë in 'n uitverkiesing wat gegrond is op 'n algemene begenadiging in Christus nie, maar daarop dat kragtens die Raad van God die uitverkiesing in Christus die saamvergadering van die uitverkore mensheid op die oog het. Die kerk van Christus moet hierdie ontbrekende deel van die uitverkiesing byeenvergader, ${ }^{136}$ ) en daar is dan ook deur die Heilige Gees in die kerk 'n onkeerbare gerigtheid op hierdie pleroma van die uitverkiesing gele $\hat{e}^{137}$ ) wat as die nuwe mensheid onder en in Christus deur Christus aan die Vader oorgegee word (1 Kor. 15:24), as die volk wat God uit die wêreld aan Christus gegee het (Joh. 17:6, 9, 12).

Hierdie universele betekenis van die uitverkiesing sluit ook in dat, aangesien dit aangeneem word dat daar uitverkorenes onder alle volke is, die Woord van oordeel en genade aan alle nasies verkondig moet word (Matt. $\left.28: 19) .^{138}\right)$

Hoewel die gemeente 'n heilige gemeente is, is daar 'n universaliteit wat so wyd is soos die wêreld en alle tye omvat, en hoewel die gemeente antiteties staan teenoor die sonde en die ryk van die duiwel en geroep is om die stryd daarteen aan te bind, is daar vanweë die absolute genade-karakter soos dit geopenbaar word in die uitverkiesing, 'n sterk solidariteitsgevoel en drang met die wêreld ook buite die kerk, want ooreenkomstig die utverkiesingsleer moet van die veronderstelling uitgegaan word, dat hoewel nie alle mense voorwerpe is van die uitverkiesing nie, selfs die slegste en mees vyandige mede-sondaar 'n moontlike voorwerp van die genadeverkiesing kan wees. ${ }^{19}$ )

\section{(iii) Die Eskatologiese:}

As derde konstituerende moment vir die kerkbegrip met die oog op die bepaling van die betekenis van die sending het ons genoem die eskatologiese.

As reaksie teen die kerklike sending is aangevoer dat daarmee die sending 'n aangeleentheid net van ampsdraers word en ten tweede dat met kerkplanting as doel sulke gestigte kerke introvert op hulleself gerig bly sonder enige missionêre bewoënheid. Die doel van die sending moet dus verder strek as die bloot kerklike. Dit moet gerig wees op die koms van die basileia. ${ }^{140}$ ) 
Al is dit waar dat die einddoel van die sending betrekking het op die basileia, moet daar gewaak word teen 'n ooraksentuering van die eskatologiese moment, tot devaluering van die kerk en die kerklike aspek van die sending. ${ }^{101}$ )

Daarbenewens moet opgemerk word dat bogenoemde twee besware teen 'n kerklike sending verval as die kerk as sendende orgaan en sending as kerkplanting in skriftuurlike lig gesien word.

Insake die eerste beswaar is reeds genoem dat onder kerklike sending verstaan word ' $n$ aangeleentheid van die hele gemeente en nie net van die ampsdraers nie.

Teenoor die tweede beswaar moet gestel word dat kerkplanting ook as doel gesien moet word mits dit in die N.T. betekenis verstaan word. Daarvolgens moet die kerk in die heilshistoriese verband gesien word as die nuwe volk van God wat uit al die volke vergader word, in die christologiese verband as die liggaam van Christus en in die eskatologiese verband as die erfgenaam van die koninkryk. As sodanig moet die geplante kerke dus ook gerig wees op die volke, die koms van Christus en sy koninkryk. ${ }^{122}$ )

Dit moet toegegee word dat die doel verder strek as die bloot kerklike en dat die einddoel gerig moet wees op die basileia. Daarom bevredig die doelstelling van Voetius nie heeltemal nie. Volgens hom het die sending 'n drievoudige doel nl. die conversio gentilium, die plantatio ecclesiae en die gloria et manifestatio gratiae divinae. (1)' Volgens dr. Bavinck' (19) egter is hierdie drie doeleindes in wese niks anders as drie aspekte van die een magtige oogmerk van God nie, wat die koms en die verbreiding van die basileia genoem kan word.

Hierdie relasie van sending en basileia volg uit die betrekking waarin die kerk tot die basileia staan. ${ }^{145}$ ) Hierdie verhouding word baie duidelik in die Skrif aangegee. Daarvolgens is die kerk die volk van die basileia. „Die apostels gee aan hierdie verhouding gestalte en bring die bepaaldheid van die kerk deur die koninkryk tot uitdrukking. Hulle gee aan die kerk die struktuur van die eskatologiese gemeente" ${ }^{14 k}$ ) wat as sodanig nie net prinsipieel van die wêreld onderskei is as die heilige gemeente wat die terugkoms van die Koning verwag nie, maar ook as die koninkryksgemeente wat vry onder die mag van sy Here staan en 'n sout en lig is vir die hele lewe in al sy verhoudinge en verbande en ook as die sendinggemeente wat ekstensief in die ruimte van die koninkryk gestel is met die opdrag om die evangelie aan alle volke te verkondig. ${ }^{107}$ ) Hierdie universele strekking volg uit die wêreldomvattende omvang van die koninkryk van God, wat die ganse nuwe mensheid omvat.

Sending is eskatologies gerig op hierdie universaliteit van die koninkryk van God en daarom is sending, eskatologie en universaliteit onlosmaaklik met mekaar verbind. ${ }^{148}$ ) 
En sending moet dan ook in die eerste plek van alle ander werksaamhede in die koninkryk van God onderskei word deur hierdie totalitêre gerigtheid op die eindes van die aarde en die tyd $\mathrm{d}^{149}$ ) en verder daarin dat die kerk uitgestuur word na nie-christelike volke. Daar kan dus nie sprake wees van sending onder ontkerstende volke nie. In die laaste geval moet van evangelisasie gespreek word. ${ }^{150}$ )

Oor die eskatologiese het daar in die jongste tyd baie publikasies verskyn en daar is nog baie onopgeloste vrae hieroor. Op dit alles kan nie ingegaan word nie en ook nie op die verskillende teorieë hieroor soos die konsekwente eskatologie van Albert Schweïtzer, die „realized eschatology" van Dodd en die eksistensiële eskatologie van Bultmann nie. Ons beperk ons slegs tot die belangrikste momente wat kan dien om meer lig te werp op die betekenis van die sending en volstaan verder deur te verwys na die belangrikste literatuur oor die eskatologiese element. ${ }^{151}$ )

Die eskatologiese moet egter nie gesien word as 'n korreksie of 'n byvoeging by die Christologiese nie, want die Christuskerk is vanselfsprekend gerig op die wederkoms van die Here van die kerk. Dit volg ipso facto uit die christologiese karakter van die kerk. Verder moet gewaarsku word teen die oordrywing van die eskatologiese asof dit die enigste bepalende moment is ${ }^{152}$ ) en teen die isolering daarvan van die ander skrifverbande van skepping, sondeval en verlossing. ${ }^{1{ }^{3}}$ ) Ook kan dit nie as sendingmotief los van die ander sendingmotiewe bepalend wees vir die sendinghouding nie..54)

Ter voorkoming van 'n eensydige ooraksentuering van die eskatologiese enersyds en 'n juiste waardering van die groot belangrikheid daarvan andersyds moet dit gesien word vanuit die Raad van God. Daar moet agteruit gekyk word na die Raad van God en vooruit na die vervulling daarvan in die eindtyd. En in hierdie vervulling het die sending van die kerk 'n belangrike funksie. Verder moet die eskatologiese profeties-eskatologies gesien word, in die sin dat in en vanuit die hede die eskaton wat aankom gesien word..$^{155}$ )

Die belangrikheid van die eskatologiese in die sending blyk daaruit dat Christus self die twee momente in 'n wesenlike en fundamentele relasie gestel het met hierdie woorde: „en hierdie evangelie van die koninkryk sal verkondig word in die hele wêreld tot 'n getuienis vir al die nasies; en dan sal die einde kom" (Matt. 24:14 vgl. Mark. 13:10 en Hand. 1:6-8, asook 2 Tim. 1:9-10, Luk. 24:46-49). „De boodschap die het apostolaat is opgedragen is een eschatologiese, de richting waar in het apostolaat zich beweegt is die naar het einde; omgekeerd wordt gezegd dat het einde niet zal komen aleer het apostolaat is volbracht". ${ }^{136}$ )

In hierdie verbinding van eskatologie en sending word die volgende duidelik : 
(a) Die sendingprediking wat 'n aanvang geneem het na die uitstorting van die Heilige Gees is nie net 'n teken van die einde nie, maar ook 'n teken dat die einde reeds gekom het. Dit is soos Holsten dit uitdruk nie net voorafgaande aan die einde nie maar ook opgeneem in die einde. ${ }^{157}$ )

Dat die evangelie eers aan alle nasies verkondig moet word voordat die einde kom, was natuurlik 'n bekende feit en word duidelik aangegee in die Skrifgedeeltes wat hierbo aangehaal is, maar as vrug van verdere teologiese studie word nou feitlik algemeen ingesien dat die sendingprediking wat moet uitgaan na alle nasies ook karakteristiek is vir die einde wat alreeds gekom het. ${ }^{159}$ )

Met Christus se koms op aarde het die koninkryk gekom en deur hierdie beloofde en verwagte Messias is alles vervul wat moes dien tot verlossing en versoening van die wêreld; die beslissende oorwinning oor die dood en die duiwel is reeds behaal ${ }^{199}$, en daarom het nou die tyd aangebreek van die welbehae vir die heidenvolke en is die weg geopen vir die verkondiging aan alle volke van die evangelie-boodskap van die behaalde oorwinning en verlossing as heilsfeite. ${ }^{160}$ )

Byna deurgaans word dan ook, waar oor sending in die Ou Testament gespreek word, dit gesien in messiaans-eskatologiese lig, ${ }^{161}$ ) en die heilshistoriese plek van die sending is dan ook in hierdie eindtyd tussen Christus se hemelvaart en sy wederkoms. Dit is die laaste akte in die groot wêreldprogram van God voor die volgende met die voleinding. ${ }^{162}$ )

So is sending self 'n eskatologiese gebeure, ${ }^{163}$ ) dit waarop die eindes van die aarde gewag het, maar omdat dit nog ' $n$ voorlopige vervulling is van alles, is die koms van die koninkryk vir die oë van die ongelowige nog verberg, en volg uit die vervullingskarakter van Christus se versoeningswerk dat die openbaring daarvan veral gesien word in die prediking, en so word veral in die sending gesien die voorlopige realisering van die verwagte heilstyd. ${ }^{104}$ )

Maar vir die gelowige het die einde reeds aangebreek, die eindfase van die wêreldgeskiedenis het reeds ingetree.

(b) Daarom is die koms van die koninkryk in sy heerlikheid met die voleinding seker en vas, sò seker dat dit steeds aangevoel word as 'n nabye presonte werklikheid. ${ }^{165}$ ) Maar daaruit volg nie dat daar met die "Zwischenzeit" 'n moratorium intree en dat alleen maar gewag moet word vir die terugkoms van Christus nie, want uit die indikatief van die vervulling volg die imperatief van die hede: omdat die koninkryk gekom het en die wêreld reeds in beginsel verlos is en die beslissende slag reeds gelewer is, moet die gelowiges hulle lampe brandende hou (Matt. 25:1-13), woeker met die ponde wat aan hulle toevertrou is (Luk, 19:11-28) en waaksaam wees (Luk. 12:35-48), en die verlossingsfeit moet aan die volke verkondig word en hulle moet opgeroep word om hulle onder die koningsheerskappy van Christus te stel. 
Daarom kan ons bid: Laat $u$ koninkryk kom, want aan $\mathbf{u}$ behoort die koninkryk. ${ }^{166}$ )

Dit is ook nie so dat nou dat die koninkryk gekom het daar in die tussentyd niks gebeur nie. Inteendeel die hede is vol koninkryksgebeure. Al groei die koninkryk soos 'n saad is dit in sy groeikrag onkeerbaar en is die oes groot (Matt. 13:7-23). ${ }^{167}$ )

En as Jesus aan sy dissipels sê: aan My is gegee alle mag in hemel en op aarde, gaan dan heen ..... (Matt. 28:18-19), bedoel Hy nie hiermee dat nou dat $\mathrm{Hy}$ alle mag ontvang het hierdie feit net meegedeel moet word nie, maar ook en veral dat „deze macht op aarde een feit wordt in de Christusverkondiging op aarde. Het zendingwerk is zelf de aardse manifestatie van Christus' verheerlijking"'. ${ }^{168}$ )

Daarom is hierdie tyd nie net 'n tyd van voorbereiding van die koms van die koninkryk nie, maar die kragte van die toekomstige wêreld is reeds nou werksaam in die hede (Hebr. 6:5). ${ }^{169}$ )

Die koninkryk word deur die sendingprediking reeds openbaar in die ekklesia wat die katolieke gemeente en die vrygeworde koninkryksvolk is, die volk wat in alle lewensverhoudinge en -verbande 'n sout en lig is en wat as die heilige gemeente die antitese oproep in die wêreld.

Voorts bepaal die sending ook mede die sin van die geskiedenis. ${ }^{170}$ ) Die einde moet wag op die sendingwerk wat eers afgedoen moet word: so word „de wanden der geschiedenis uiteengehouden" hierdeur. ${ }^{171}$ ) Met die oog op die sendingtaak wat eers afgedoen moet word, word die eindtyd as 't ware nog verskuif. ${ }^{172}$ ) Hierdie verskuiwing is egter nie 'n vertraging soos dit vertolk word deur die konsekwente eskatologie nie dat $\mathrm{nl}$. 'n vergissing ingetree het en die einde toe eers later verwag is, maar deur die lankmoedigheid van God (2 Pet. 3:9 ${ }^{173}$ ) word die einde as 't ware vertraag sodat daar vir die volke 'n tyd van welbehae intree waarin die evangelie aan hulle verkondig word. ${ }^{174}$ ) Daarbenewens is dit nodig dat die volle pleroma van die volk van God eers ingesamel word, ${ }^{17 *}$ ) en die groot krisis van die kruis van Christus moet eers deur die sending deurwerk tot 'n globale afskeiding van die koninkryksgemeente oor die hele wêreld en die rypwording van die antichristelike magte vir die finale oordeel van God. ${ }^{17 *}$ )

Daarom is sending mede die sin van die geskiedenis. Omdat Christus alle mag ontvang het, lei $\mathrm{Hy}$ ook in die geskiedenis alles tot die koms van sy koninkryk (vgl. Openb. 5) ${ }^{177}$ ) en laat $\mathrm{Hy}$ ook die huidige wêreldkrisis ontstaan, maar skep Hy ook daarin en daardeur die geleenthede vir die uitbreiding van sy koninkryk ${ }^{178}$ ) deur die amptelike diens van sy koninkryksgemeente wat met die profetiese woord teenoor die wêreld maar ook in diens aan die wêreld staan.

(c) Deur die sendingsopdrag in Matt. 28:18-20 is die kerk in sy sending gerig op die eindes van die aarde en die tyd, op al die volke, al die dae tot aan 
die voleinding en alles moet geleer word vir die hele lewe om dit te onderhou. Hierdie opdrag is totalitêr in ruimte, tyd en intensiviteit. Daardeur word die kerk eskatologies gerig op daardie totaliteit. Alleen wanneer in alle sendingarbeid die uitsig so totalitêr-eskatologies is, het dit ware sin en betekenis en gaan daar ' $n$ dinamiese werfkrag van die kerk uit en is daar 'n besielende en hoopvolle verwagting. ${ }^{179}$ )

So word in die sending geopenbaar die organisme van die soma wat groei tot sy pleroma van die uitverikiesing en hierin is die sending 'n onmisbare skakel $^{100}$ ) as die kerk wat die ontbrekende deel van die uitverkiesing soek.

(d) Sending is ten slotte ook 'n teken van die einde - eers moet die evangelie aan alle volke verkondig word, dan sal die einde kom. Eers wanneer dit aan alle volke verkondig is tot ' $n$ getuienis van oordeel en heil, tot die uitwerking van die groot antitese oor die hele wêreld en die volle pleroma ingesamel is, is die voleinding daar. So is sending ' $n$ teken van die eindtyd wat kom.

In hierdie lig word die verhouding van die sending onder die heidene en diè onder Jode duidelik. ${ }^{131}$ ) Israel se verwerping bring mee dat die stroom van die evangelie wegvloei van Israel na die heidene. So moes dit gebeur, maar deur die deurwerking van die evangelie onder die heidene vloei dit weer terug na Israel, en so tree die saligheid van die pleroma van Israel in wat na die verkiesing is (Rom. 9-11).

Israel kan nie sonder die heidene in die koninkryk ingaan nie, maar die kerk uit die heidene kan die einde van die wêreldtyd ook nooit haal sonder die pleroma van Israel nie.

So is die bekering van Israel ook 'n teken van die naderende einde net soos alle sendingwerk 'n teken is daarvan, en terwyl die sendingwerksaamhede vir die eerste maal in die geskiedenis in hierdie 20ste eeu feitlik tot aan die eindes van die aarde uitgebrei het, ${ }^{182}$ ) is dit ' $n$ sprekende teken dat die einde nie meer ver is nie.

Maar terwyl die sending ook die krisis en die antitese oproep, is die weg na die kairos van die uiteindelike finale krisis 'n aaneenskakeling van kairospunte wat as voortekens heenwys na die finale kairospunt. ${ }^{\text {(a) }}$ ) Dit is die kairospunte van die voorlopige rypwording van die sonde in 'n gesekulariseerde wêreld, met ' $n$ vryheid sonder God wat lei tot chaos en vernietiging en die antichristelike keersy van die vrygeworde koninkryksgemeente is, wat in die kairoi gedring word tot 'n profeticse antitese daarteenoor. ${ }^{134}$ )

So is ook die huidige wêreldkrisis die klimaks, die kairospunt van die historiese proses van die afgelope vier of meer eeue ${ }^{105}$ ) wat lei tot die openbaarmaking van die koninkryksgemeente aan die een kant maar ook van die antichristelike magte wat tot hulle katastrofale einde kom. 
Daar moet by die kerk wees 'n lewenshouding van konstante eskatologiese gerigtheid op die einde, maar ook in die kairospunte in die geskiedenis moet telkens weer profeties gesien word die groot eskaton wat aankom. Die gemeente moet ,forward living" "166) wees deur van dag tot dag op te merk hoe die beloftes van God in die hede vervul word en hoe die groot eskaton aankom in die magtige dade wat God deur sy kerk van dag tot dag in die geskiedenis verrig. Daar moet die geloof wees dat God deur ons arbeid - alle arbeid in sy koninkryk tot sy eer, maar veral die sendingarbeid -... magtige dade tot die koms van sy koninkryk verrig. ${ }^{187}$ ) Alleen met hierdie geloof en wanneer ons self nie in die weg van sy wêreldomspannende koninkryksarbeid is nie, maar ons self in hierdie diens van Hom stel, kan daar die besielende oortuiging wees wat lei tot 'n dinamiserende uitsig op die sekerheid van die paroesie in die groot heerlikheid.

Maar dan nie in die sin dat die koninkryk deur ons arbeid kom nie, maar daarin dat wat ons hierin verrig die arbeid van God is. ${ }^{1 *}$ ) Die voleinding kom ook nie deur 'n kontinue en geleidelike ontwikkeling tot ' $n$ heerlike einde nie, maar dit kom deur die oordeel oor die gerypte sonde en die herskepping en vernieuwing van die wêreld sodat Christus alles is in almal. ${ }^{149}$ )

Eers in hierdie eskatologiese lig is die betekenis van kerk en sending duidelik. ${ }^{\mid 91}$ ) Deur die sendingarbeid van die kerk word die paroesie voorberei en is die sending 'n onmisbare skakel in die groei van die soma tot die pleroma; daardeur word ook die kragte van die toekomende eeu openbaar, maar in dit alles is dit die Here wat deur sy kerk optree. Maar die kerk self is nog meer as dit: dit is ook die pleroma in kiem, die pleroma in wording. Dit is nie slegs middel om die volheid te bereik nie, dit is ook self die volheid in kiem. Die kerk self is 'n eskatologiese grootheid, 'n pleroma. Dit is die liggaam van Christus in groei $^{191}$ ) wat hom uitstrek na die ontbrekende deel van die uitverkiesing en onkeerbaar daarheen dring: „De kerk is de voorlopige en daarom ook steeds in opbouw verkerende formatie op aarde van het volk Gods, dat zijn daden roemen zal. Dat is haar raison de' etre: De kerk is de voorlopige realisering van de nieuwe mensheid der toekomende eeuw, de gemeente van het koninkrijk in embryonale vorm. Daarin ligt al de heerlijkheid én al de gebrekkigheid van de kerk samengevat". ${ }^{192}$ )

So is die kerk in sy sending gerig op hierdie pleroma van die liggaam van Christus, maar terwyl die pleroma die volk is van die basileia wat eers in sy volheid kom met die pleroma van hierdie koninkryksvolk, is dit gerig op die koms van die koninkryk van God, die pleroma van gans die skepping, die rekapitulasie van alles wat God geskep het.

Maar vir 'n juiste insig in die wesenlike van hierdie eskatologiese gerigtheid moet nie net tot die skepping teruggegaan word nie maar tot die ewige Raad van God, waarvan die skepping en die versoenings- en verlossingswerk van 
Christus tot die rekapitulasie van alles die nadere uitwerking is. Die eskaton is die volle pleroma van die Raad van God.

Maar terwyl die pleroma van alles in almal in Christus is en die koninkryksvolk in Hom verkies is, word die eintlike volheid van die Raad van God nie in die eerste plek gesien in die herstel en volheid van al die kreatuurlike nie, maar in Christus, die Hoof van die mensheid en die hele skepping, die Eersteling van die hele skepping en die Beeld van die onsienlike God (Kol. 1:15), die hoop van die nasies (Rom. 15:12) in wie en tot wie alle dinge geskape is (Kol. 1:16), sodat die ganse volheid in Hom sou woon (Kol. $1: 19$ ) en $\mathrm{Hy}$ alles tot volheid kan bring ( Ef. $4: 10$ ).

Dit dan is die misterie van die Raad van God en van sy werk in die tyd „na sy welbehae wat $\mathrm{Hy}$ in Homself voorgeneem het, om die volheid van die tyd te reël, met die doel om alle dinge wat in die hemele sowel as wat op die aarde is, onder een hoof in Christus te verenig - in Hom in Wie ons ook 'n erfdeel ontvang het nadat ons vantevore daartoe verordineer is ooreenkomstig die voorneme van Hom wat alles werk volgens die raad van sy wil, sodat ons kan wees tot lof van sy heerlikheid"' (Ef. 1:9-12).

En waar die gemeente deur die Heilige Gees aan Christus verbind is en in Hom is, is die gemeente nie alleen die afstraling van die volheid in die Raad van God en in Christus nie, maar is dit ook deur die Heilige Gees in diens gestel tot die groei van die soma tot die pleroma en is dit verder deur die Heilige Gees in Christus eskatologies gerig op die volle pleroma van al die kreatuurlike in Christus, wat God „uit die dode opgewek het en laat sit het aan sy regterhand in die hemele . . . . . en $\mathrm{Hy}$ het alle dinge onder sy voete onderwerp en Hom as Hoof bo alle dinge aan die gemeente gegee, wat sy liggaam is, die volheid van Hom wat alles in almal vervul" (Ef. 1:20-23).

Die sending van die kerk van Christus word hiermee in 'n alles omvattende kosmiese en ewigheidsperspektiewe lig gestel, in 'n uitsig van oneindigheid en volheid, in teleologiese gerigtheid op die allesinsluitende telos.

Ons het nou so ver gevorder dat vasgested kan word wat die wesenlike van die sending is en of en in hoeverre dit tot die wese van die kerk behoort. Uit die voorafgaande is dit reeds duidelik dat dit nie soos die apostolaatsteologie leer, ${ }^{193}$ ) die wese van die kerk is nie, want die kerk is meer as die sending, maar op grond van wat reeds gesê is moet aangeneem word dat die sending van die kerk nie 'n insidentele funksie van die kerk is wat net so goed nagelaat kan word nie. Dit is wel deeglik 'n wesenlike aspek van die kerk. Volgens Bavinck ${ }^{194}$ ) behoort die missionêre "handele" terdeë ook tot die wese van die kerk, en volgens van Swigchem ${ }^{195}$ ) kan die plek wat die sending in die lewe van die kerk inneem, omskrywe word as 'n wesenlike element of noodsaaklike aspek daarvan, en $\mathrm{H}$. Boer ${ }^{196}$ ) is van gedagte dat met pinkster die uitwendige sendingbevel ook nou die wesenlike lewenswet van die kerk geword het. 
Ons sou sending wil definieer as 'n wesenlike diaconia Christi wat die Heilige Gees in die periode tussen die hemelvaart en wederkoms van Christus deur sy kerk uitvoer tot openbaring van die voorlopige koms van sy koninkryk, tot die byeenvergadering van die pleroma van die uitverkiesing en tot voorbereiding van die koms van sy koninkryk. Die kerk verrig hierdie amptelike diens in eskatologiese gerigtheid op die koms van die koninkryk tot eer van God as sy ambassadeurs en instrument deur die verkondiging van sy Woord van oordeel en heil aan alle nie-Christelike volke, die oproep aan hulle tot bekering, die planting van kerke onder hulle en deur hulle alles te leer wat Christus beveel het om te onderhou.

\section{DIE MISSIOLOGIE EN DIE SENDING OIJ.EK IN DIE KONKRETE \\ SITUASIE.}

Omdat sendingdiens amptelike diens aan die nie-christlike mensheid is, moet die missiologie, om waarlik vrugbaar te wees, ook rekening hou met die geadresseerde mens in sy konkrete situasie soos God hom daar toespreek en soos hy deur die sending toegespreek moet word.

Omdat die sending soos geen ander kerklike diens so totalitêr en direk gerig is op die eindes van die aarde en die tyd, en in die historiese proses in die "Zwischenzeit" so 'n belangrike funksie vervul en dit kom met 'n boodskap aan die mens in ' $n$ wêreld wat alreeds in beginsel verlos is en warin God die mens steeds toespreek, moet die missiologie ook soos geen ander teologiese wetenskap nie in betrekking staan tot die historiese en kontemporêre werklikheid in maatskaplike, etnologiese en internasionale omvang en verbande.

In hierdie konkrete omgewing is daar in die eerste plek die geadresseerde heiden wat in sy heidendom gekonfronteer moet word met die appellatiewe kerugma, tot oorgawe, loslating van die oue en tot bekering oor die hele front van die lewe. Teenoor hierdie heiden met sy nog lewende godsdiens, sy primitiviteit en sy kulturele en religieuse agtergrond en sy heidense religiositeit, moet die Woord in al sy eenvoud en betekenisvolle diepte vir die hele konkrete lewe verkondig word.

Daarvoor is nodig dat aangesluit word by die spreke van God tot die heiden ${ }^{197}$ ) en dat die wese en betekenis van sy heidendom deursien word, maar ook dat die Woord in al sy diepte verstaan word en in ' $n$ heldere eenvoud weergegee word om die heiden in sy besondere situasie te benader met ' $n$ sprekende en toepaslike konfrontering en 'n direkte ontmoeting met die kerugma.

Daarbenewens moet vir die planting van die kerk onder die heidendom met die eiesoortige etniese agtergrond rekening gehou word, en vir hierdie nuwe planting en fondamentwerk is dit nodig dat 'n vaste teologiese fundering gevind word en dieper besin word oor sulke ingewikkelde vrae soos dié wat betrekking het op die wese van die kerk, die eienskappe en kenmerke daarvan, die verhouding van. ou en jong kerke, die kerklike konfessie, liturgie en kerkorde vir die jong kerke, die roeping van die gelowiges in hulle heidense 
omgewing en teenoor hulle eie mense en baie ander ingewikkelde missionêre probleme soos dié in verband met die akkomodasie- en aanknopingsvraagstuk, die organe, praktyk en doel van die sending, e.d.m.; daar moet verder ook die nodige insig verkry word oor die sending in die geskiedenis, die geskiedenis en die sending e.d.m.

Vir dit alles moet die teologiese antwoorde gevind word, wat God self sê in hierdie nuwe omstanddighede en in die konkrete situasies en omgewing van die sendingarbeid self.

Hiermee word nie alleen nuwe asook ou teologiese temas in 'n nuwe situasie aan die teologie voorsien nie, ${ }^{148}$ ) maar word ook telkens nuwe lig gewerp op ou waarhede en is dit duidelik dat ,for theology it is a matter of life and death that it should be in direct contact with the missionary enterprise". ${ }^{199}$ )

Maar in die veranderde wêreld is ook die nuwe heiden die geadresseerde. Die algemene tendens in die wêreld en steeds meer ook in die heidenwêreld is, as indirekte neweproduk van die sendingprediking en as antipode en antitese van die Christelike sekularisasie, in die rigting van antichristelike sekulêre vryheid en vooruitgangstrewe uit die vroeëre heidense natuur- en gemeenskapsgebondenheid ${ }^{200}$ ) tot die massamens in die massale koltektiviteit. ${ }^{211}$ )

In die breë wêreldstroom word nou as gevolg van 'n nuut ontwaakte nasionale besef by die nie-westerse nasies of volksgroepe 'n volwaardige plek in ekumeniese verband in die ry van die nasies geëis sonder dat egter eie identiteit prysgegee wil word. ${ }^{202}$ )

En in hierdie nuwe wêreld wat een groot ,wêreld geword het, is daar 'n nuwe gevoel van ,ecumenical togetherness", 'n kosmopolitiese eenheidsgevoel van die een mensheid. ${ }^{203}$ )

Hiernaas is daar egter skerp botsende nasionale belange en aspirasies asook 'n vernieude heidendom wat egter nog geen bewys gelewer het dat dit as 'n fondament vir die nuwe wêreld kan dien nie, ${ }^{204}$ ) maar waarin (m.n. in die Boeddisme, Islam en Hindoeïsme) aan die ander kant die nuwe hoop van die wêreld teenoor die „mislukte" Christendom gesien word. ${ }^{205}$ )

En in dit alles is God besig om alles te lei en te bestuur tot die koms van sy koninkryk, en laat $\mathrm{Hy}$ dit mede deur die sending kom; daarvoor laat $\mathrm{Hy}$ die nasies vry word en skep $\mathrm{Hy}$ ook nou in die skynbaar ongunstige wêreldomstandighede geleenthede vir die sending ${ }^{206}$ ) en bring $\mathrm{Hy}$ die wêreld deur krisisse en skeidinge tot die finale krisis en skeiding.

In hierdie nuwe wêreld, met sy baie aanpassings-, akkulturasie- en verhoudingsprobleme, met sy botsende belange en pynlike groeiprosesse asook met 'n vergaande disintegrasie, het die kerk as die koninkryksgemeente die roeping om profeties te getuig teen alle tirannie, geestelike en materiële verslawing en onware vryheid. Die kerk het in die Woord van God 'n vrymakende en revolusionerende boodskap wat soos dinamiet teen alle onreg, verknegting, sonde- 
bande en menslike selfsug inwerk. ${ }^{20 \pi}$ ) Verder moet die kerk as Christuskerk dic geestelike, ekonomiese en maatskaplike nood van die mens simpatiek benader en daarvoor aan die mens die verlossende woord spreek in sy verlange na vryheid, vooruitgang, gemeenskap en verlossing. ${ }^{208}$ ) Maar die kerk moet ook soek om die werklike vrae wat agter hierdie vrae skuil te ontdek, en dit moet hoor wat God self tot die mens spreek en watter vrae $\mathrm{Hy}$ aan die mens stel. ${ }^{209}$ ).

In 'n werklike ontmoeting met ou en nuwe heiden in sy besondere situasie moet die antwoorde en vrae van die mens in sy religie, sy lewenshouding, sy lewensbeskouing, geestesrigting en sy nood onderwerp word aan die vrae van die Woord van God om so die sondige daarin te ontmasker en die diep geestelike antitese daarvan met die ware geluk, vryheid, saligheid, waarheid en gemeenskap aan die lig te bring. ${ }^{210}$ )

Alleen in so ' $n$ ware ontmoeting met die ongelowige in sy ou en die nuwe wêreld kan die verlossende en bevrydende woord vir die hele lewe tot die siel van die mens spreek, en alleen op hierdie ontmoetingsweg ontvang die kerk weer nuwe lig, word dit weer teruggedring tot sy diep geestelike fondament en tot die volle aanvaarding van sy roeping in die besef van die betekenis van wat die ware kerk is. ${ }^{21}$ )

Op bogenoemde missiologiese vrae en die vrae van die mens probeer ook die teologie buite die Gereformeerde erf om die antwoorde te vind, en hoewel die verborge vrae van die mens nie altyd deursien word nie en die Woord van God nie altyd in sy volle diepte en waarheid spreek nie, moet tog erken word dat hierdie teologie soms meer betrokke stann tot die konkrete werklikheid van die nie-gelowige wêreld as die Gereformeerde teologie wat tot sy eie armoede soms meer negatief en reaksionêr daarteenoor staan en soms vergeet dat die Heilige Gees ook buite die Gereformeerde teologie werk. ${ }^{212}$ ) Tog is die Gereformeerde teologie telkens ook hierdeur gestimuleer tot verdere besinning oor die ou waarhede in die nuwe situasies, en so is daar by die lig van die Skrif ook weer verrassende nuwe insigte verkry soos uit die vooorafgaande blyk, bv. insake die verhouding van die openbaring tot die pseudo-religie, die uitverskiesing en die solidariteitsvraagstuk, die uitverkiesing, die verbond en die universaliteit van die verlossingsplan van God; die verskillende vraagstukke in verband met kerk en sending, soos die wese van die sending, die eskatologiese aspek van kerk en sending, die verhouding van kerk en sending en die basileia e.d.m.

God wil aan sy kerk nuwe lig op sy waarheid skenk as die teologie in 'n ontmoeting tree met die mens in sy vrae en antwoorde, ook met die mens in sy teologiese probleemstellinge en antwoorde. So alleen kan die toepaslike woord vir die besondere konkrete situasies gevind word en die weg gevind word vir die opkomende probleme.

Dit geld veral vir die missiologie, maar dan moet dit alles teologies gesentreer wees, d.w.s. dit moet gaan om die cognitio Dei, om wat God sèlf 
tot die mens spreek en wat sy vrae aan die mens is en wat sy antwoord is. Daarom moet die menslike vrae en antwoorde steeds in alles getoets word aan die Woord van God en die Reformatoriese konfessie by watter lig alleen die waarheid asook die leuen geopenbaar en nuwe lig verkry word oor ou waarhede. ${ }^{213}$ )

Ook by die konfessie, en die nuwe moet ook dien om weer die ou waarhede van die konfessie in ' $n$ nuwe lig te stel en dit verder uit te bou en nie om dit af te breek en ook nie om telkens weer 'n nuwe teologie van die grond af op te bou nie. Die rigting van ontwikkeling moet wees in die lyn van die Reformatoriese konfessionele geloofsuitdrukking, omdat God ook so in die verlede in die worsteling van die herbore mensheid in die Reformatoriese lyn sy waurheid geopenbaar het en die subjek van die teologie nie net die kontemporêre gelowige geslag is nie maar die herbore mensheid van olle eeue, ${ }^{214}$ ) mar dan nie so dat die konfessie 'n onfeilbare principium is naas die Skrif nie maar as 'n nadere geloofsverklaring en vitdrukking van die Skrifwaarhede wat ook as menslike werk nie volledig en afgedoen is nie, nie 'n absolute norm is nie en steeds aan die gesag van die Skrif onderwerp moet word. ${ }^{215}$ )

By die lig van die Woord en die konfessie word dit duidelik dat alleen maar die antitese in die nie-gelowige antwoord gevind word en dat by die teologie wat nie die Skrif as die geïnspireerde voorwerp en principium van die teologie erken nie en die konfessie verwerp, die antwoorde meestal ambivalent is net soos die sendingmotiewe in die loop van die sendinggeskiedenis meestal ambivalent was en is. ${ }^{216}$ ) By laasgenoemde teologie is daar enersyds 'n erkenning van Skrifwaarhede wat soms lei tot verrassende nuwe insigte, maar andersyds is daar, deur verwaarlosing of ontkenning van ander momente of die veronagsaming van die Skrifverbande, 'n verkragting van hierdie waarhede. Een moment word gewoonlik ooraksentueer en daar word 'n eensydige sintese gesoek met verwaarlosing en uitsluiting van ander momente wat betrekking het op dieselfde saak. ${ }^{217}$ ) Maar net soos die toepaslike Woord van God vir die heiden nie gevind kan word nie as die dialoog van God met die heiden buite rekening gelaat word, en net so min as wat die antwoord vir die kontemporêre situagies ten volle as 'n toepaslike woord van God verkry kan word as nie na die dialoog van God met vorige geslagte geluister word nie, net so min sal die toepaslike woord vir die nuwe heiden gevind word as nie geluister word na die dialoog in die kontemporêre situasies nie. ${ }^{218}$ )

As hiermee nie rekening gehou word in die teologiese studie nie sal dit aan bloedarmoede ly en nie altyd die volle lig op ou waarhede verkry nie. Dit wil egter nie sê dat alleen op hierdie wyse nuwe goud uit die ou myn ontdek word nie. Daarvoor is die direkte studie van die Skrif onontbeerlik.

Die volgende aanhaling gee min of meer die voorafgaande saamvattend weer: „This theology (d.i. missiologie) has to be ecumenical in that it knows 
that only together with all saints is it able to comprehend what is the breadth and length and depth and height (Eph. 3:18) of the dimensions of the Church's mission, and reformatory in that it sees in the reformation a purification of the Church in her broadest scope and her widest activities. It has to be confessional in that in the problems around the kerygma which has to be transmitted, it wants to listen together with the "fathers" to the voice of God, while at the same time it has to possess a sense of understanding contemporaneity with our own searching and struggling, despairing and expecting age. And above all it has to be scriptural in that it sees in the Word of God, in the Bible, the only rule for faith and order, for life and work, for missions and evangelism. ${ }^{219}$ )

\section{DIE ENSIKIJOPEDIESE PI.EK VAN DIE MISSIOIOCIIE.}

Omdat soos in die voorafgaande reeds aangetoon is die sending nie die wese van die kerk is nie, kan die voorstel van die apostolaatsteologie, ${ }^{220}$ ) dat die hele teologie vanuit die apostolaatsgedagte hersien moet word, nie aanvaar word nie. Wel is dit waar dat die missionêre aspek in die ander teologiese wetenskappe in die reël nie tot sy reg kom nie, dat die sending soms sy temas aan die teologie voorsien en dat die missiologiese studie ook bevrugtend is vir die teologie in die algemeen. ${ }^{221}$ )

Nie 'n nuwe apostolaatsteologie is nodig nie, maar wel dat die missiologie as 'n teologiese wetenskap sy regmatige plek in die organisme van die teologie kry, waarmee moet saamgaan 'n meerdere erkenning en toepassing van die missionêre aspek in die teologie in sy geheel en dele. Sonder die missiologie is die teologie inkompleet. Daarom moet die missiologie, net soos enige ander teologiese wetenskap, ingesluit word in die leergang vir alle teologiese studente. ${ }^{22}$ )

M.b.t. die bepaling van die ensiklopediese plek van die missiologie is daar die volgende moontlikhede:

(a) integrering daarvan in alle of byna alle teologiese vakke;

(b) missiologie as 'n hoofgroep;

(c) 'n selfstandige wetenskap) onder een of meer hoefgroepe.

Wat die eerste moontlikheid betref is die feit dat byna alle teologiese vakke ook 'n missionêre aspek het nog nie 'n genoegsame grond vir die integrering van die missiologie in al hierdie vakke nie. Dit volg uit die aard van die teologie as 'n organiese wetenskap dat die geheel nie 'n optelsom van die dele is nie maar dat die dele onderling verband met mekaar in die organiese geheel het, en al is die missiologie miskien nouer as een van die ander dele met die hoofgroepe en die ander onderdele verweef, moet dit as 'n selfstandige wetenskap beskou en behandel word, want hierdie ,een karakteristieke gezichtspunt, namelijk het missionaire aspect van de kerk, brengt al die elementen tot elkander en constitueert de zendingswetenschap". ${ }^{23}$ ) Om hierdie rede verdien 
die benaming sendingwetenskap of missiologie dan ook die voorkeur bo ander benaminge vir hierdie wetenskap. ${ }^{224}$ )

Maar die tweede moontlikheid, nl. van ' $n$ aparte hoofgroep, kan nie op grond hiervan geregverdig word nie, want daar sou nie 'n principium divisionis vir so 'n hoofgroep gevind kan word wat organies inpas by die ander vier en die geheel nie.

Volgens Bergema volg uit die universaliteit van die missiologie (die uitgestrektheid daarvan oor die hele gebied van die teologie en selfs daarbuite) en die eie kring daarvan (die integrasie tot 'n eie outonome wetenskap deur die missionêre aspek), dat dit as 'n selfstandige wetenskap met sy eie vakke 'n ellips binne die ellips van die teologie vorm ,,met eigen door het missionair aspect bepaalde verbindingen naar de andere theologische en niet theologische vakken". ${ }^{225}$ )

Hierdie oplossing bevredig egter nie. In die praktyk sal dit daarop neerkom dat die missiologie dan tot 'n groot mate as ' $n$ tweede selfstandige grootheid sonder organiese verband met die teologie in sy geheel en sy ander dele te staan sal kom. Die hoof- en afdoende beswaar daarteen is egter dat, soos hieronder sal blyk, op hierdie wyse die karakteristieke van die missiologie nie tot sy reg kom nie.

Daar bly dus net die derde moontlikheid oor. Gewoonlik word die missiologie uitsluitend of hoofsaaklik onder die diakoniologiese groep geplaas. Ook A. Kuyper en J. H. Bavinck ${ }^{226}$ ) wil dit hieronder 'n plek gee.

As ons onder sending verstaan die uitsending van die kerk deur Christus in sy diakonia, dan is, soos reeds aangetoon is, sending 'n diakonia van Christus en moet die amptelike karakter daarvan op die voorgrond staan en moet die principium divisionis vir die missiologie hierin geleë wees. Die aangewese plek vir die missiologie is dus onder die diakoniologiese groep. So het dit 'n teologiese plek en so alleen bly die teologiese karakter daarvan gehandhaaf.

Insake die vakke wat hieronder ingesluit moet word wil Kuyper elenktiek (die wetenskap waarin die pseudo-religies gekonfronteer word met die Woord van God) 'n plek gee onder die groep antitetiese vakke van die dogmatologiese groep, omdat dit volgens hom meer met dogmatiese vrae te doen het met 'n antitetiese strekking, ${ }^{27}$ ) maar Bavinck toon tereg aan dat die belangrikste funksie van die elenktiek tog in iets anders geleë is as in 'n blote verweer teen die nie-Christelike religiositeit. Dit word in sterk mate beheers deur die missionêre gedagte en bedoel in die eerste plek 'n regstreekse aanval teen hierdie religiositeit om die sondige daarin te ontmasker en tot bekering te roep. Dit moet dus as ' $n$ missiologiese vak beskou word. ${ }^{228}$ )

Dr. Bavinck wil die twee hoofdele van die missiologie, nl. die sendingteorie en die sendinggeskiedenis, met die elenktiek min of meer as 'n aanhangsel by die 
eerste as 'n selfstandige wetenskap onder die diakoniologiese groep laat val. ${ }^{220}$ )

Die missiologie sluit egter meer as net hierdie drie vakke in. Volgens Bergema $^{230}$ ) en ook ander ${ }^{321}$ ) moet die godsdienswetenskappe ook as teologiese wetenskappe beskou word en in die missiologie opgeneem word, maar terwyl die voorwerp vir studie vir hierdie wetenskappe meer die mens in sy religie en die menslike religie is en hierdie wetenskappe nie elenkties-missionêr is nie, is hulle nie teologiese wetenskappe nie, hoewel hulle onmisbare hulpwetenskappe vir die missiologie is. ${ }^{232}$ )

Benewens bogenoemde drie vakke kan o.i. nog die volgende, wat deur Bergema ${ }^{22}$ ) genoem word, wel as missiologiese vakke ' $n$ plek in die missiologie kry: die geskiedenis van die missiologie, die bybelse missiologie en die diakoniologiese missiologie, met die metodiek en ensiklopedie van die missiologie as 'n inleiding tot die missiologie.

Die ander deur hom genoemde teologiese vakke, soos die sendingreg, missionêre simboliek e.d.m., regverdig egter nog nie 'n afsonderlike plek in die missiologie nie, maar na gelang 'n wetenskap tot volgroeidheid ontwikkel brei ook die vakke uit, en so is dit ook nie uitgesluit dat hierdie vakke, met uitsondering van die deur hom genoemde evangelistiek, mettertyd in die missiologie opgeneem kan word nie.

Die ander deur Bergema genoemde nie-teologiese vakke ${ }^{234}$ ) soos die wat betrekking het op die ekonomie, taal, politiek, geskiedenis, e.d.m. in soverre hulle die sending raak, kan egter, hoe belangrik hulle ook mag wees vir die missiologie en die sending, uit die aard van die saak nie as teologiese en dus ook nie as missiologiese vakke erken word nie.

Die volgende kan dus o.i. as missiologiese vakke opgeneem word: die geskiedenis, metodiek en die ensiklopedie van die missiologie, bybelse missiologie, sendingteorie, sendinggeskiedenis en elenktiek, diakoniologiese missiologie.

\section{VERWYSINGS EN AANTEKENINGE.}

1. Goodall, N., Willingen-Milestone, not Terminus in Missions under the Cross, Londen, 1953, ed. N. Goodall, p. 9 e.v.

Andersen, W., Towards, a Theology of Miksiona, Londen, 1956', pp. 9-14.

Kraemer H., The Christian Message in a non-Christian World, Londen 1938, p.40 e.v.

2. Vgl. die literatunr aangegee in The Study of Missions in Theological Cduchtion, Oslo, dl. I, 1955, dl. 2, 1957, deur O. G. Myhlebust.

3. Idem dl. 2, p.p. 287-290.

4. idem p.p. 291-298.

5. idem p. 289.

6. Hoekendijk, J. C. aangehaal deur O. G. Myhlebust; Integration or Independence in Basileí, ed. J. Hermelink en H. J. Margull, Stuttgart, 1959, p. 332. 
Uic oorsprong van die apostolaatsteologie is in Nederland met H. Kracmer, J. C. Hoekendijk en A. A. van Kuler as die belangrikste verteenwoordigers, hoewel die laaste in verskillende opsigte prinsipieel 'n eie rigting volg, terwyl die eintlike apostoleatsteologie Barthiaans georiënteer is. Die "apostolaat", waaronder verstaan word „die werk van die kerk na buite in sending. evangelisasie en dic kerstening van die lewe van die samelewing", is volgens hierdie teologie die wese van die kerk en Hoekendijk beweer selfs dat die kerk bloot 'n funksie van dic apostolaat is. Oor die apostolaatsteologie vgl. J. en H. N. Ridderbos e.a., De Apostolische Kerk, Kampen 1954 en J. A. van Wijk, Die Apostolaat van die kerk, Stofberg (?) 1958.

7. Myhlebust, O. G., Integration or Independence! in Basileia, ed. J. Hermelink en H. J. Margull, Stuttgart, 1959, p. 336.

8. Idem, p.p. 332-340.

9. Myhlebust, O. G., The Study of Missions ens. II, p. 289.

10. Vgl. artikel van Myhlebust in Basileia a.w.

11. Idem, p. 336. v.d. Merwe, W. J., Ruimte vir die Sendingwetenskap in ons Toologiene studie in Op die Horison, Junie 1959, p. 21.

12. Vgl. idem p.p. 24, 25, 26.

13. Kraemer, H., a.w., p.p. 116-118.

14. Idem, p.p. 108-109. Bavinck, J. H., Religieus Besef en Christelijk Geloof, Kampen, 1949, p.p. 154-156.

15. The Christian Message, verslag van die Jerusalemse konferensie, dl. I, Londen, 1928, p.p. 490-492, Volgens S. Neill was dic konferensie i.p.v. 'n hoogte- 'n laagtepunt in die sendingontwikkeling; Neill S., The Unfinished Task, Londen, 1958', p.p. 151-152.

16. Hocking, W. E. e.a., Rethinking Missions-A Layman's Inquiry after one humdred years, New York, 1932.

17. Gilhuis, J. C., Ecclesiologische aspecten van het Zendingswerk, Kampen, 1855, p. 34. Kraemer, H., Religion and the Christian Fuith, Londen, 1956, p.p. 222-224.

18. Hocking e.a., a.w., p. 59.

19. Vlijm, J. M., Het Religie-Begrip van Karl Barth, p. 169.

20. Schleiermacher, F. E. D., Reden liber die Religion an die ciebildeten unter thren verachteren (1799, 1899). Vgl. Bavinck, J. H., a.w., p.p. 100-105.

21. Trocltsch, E., Die Absolutheit des Christentums und die Religlonsgeschlchte, Tüblngen, 1912. Vgl. Kraemer, H., a.w., p. 63-67.

22. Vgl. Vlijm, J. M., a.w., oor dic religicbegrip van Barth.

23. Idem, p.p. 48, 169-170.

24. Bavinck, J. H. a.w., p. 158.

Vlijm, J. M. a.w., p.p. 46-48.

25 Kraemer, H., The Christian message in a non-Christian world.

26. Vgl. Van Lecuwen, R. Th., Hendrik Kracmer, dienaar der Wereldkerk, Amstcrdam, 1859 .

27. Kraemer, H., Religion and the Christian Faith, Londen, 1956.

28. Idem, p.p. 8, 31, 233, 316: The Christian Message in a non-Christian Worlul, p.p. I(th, 110, 130-141.

29. Vlijm, J. M., a.w., p. 170 .

30. Kuyper, A., Encyclopaedie der Heilige Godgeleerdheid II, Amsterdam, 1894, p.p. 190-196.

31. Bavinck, J. H., a.w., p.p. 163-180, 187-191. 
32. Vgl. Berkouwer, G. C., De Verkiezing Ciods, Kampen 1955, p. 156 e.v. Berkouwer, G. C., De Triomf der Genade in de Theologie van Karl Barth, Kampen, 1954, p.p. 83-115, 258-293.

33. Brillenburg Wurth, G. Heroriëntering, Kampen, 1955, p.p. 26-41.

Berkouwer, G. C., a.w., p.p. 271 c.v., 367 e.v.

34. Kraemer, H. The Communication of the Christian Faith, Philadelphia, 1954, Dillistone, F. W., Christianity and Communication, Londen, 1956.

35. B. Wurth, G., a.w., p.p. 40-41.

Vgl. J. S. Trimmingham, The Christian Church and Islam in West Africa, Londen, 1956", p. 42: "May it not be true that the true mission is not 'conversion', with its implication of religious superiority, but 'dialogue' . . . . . ?"

36. Kuyper, a.w., p.p. 241-249

37. Idem, p. 291 e.v.

38. Idem, p.p. 362-511.

39. Idem, p.p. 578-585.

40. Vgl. o.a.: Neill, S., Creative Tension, Londen, 1959. p.p. 81-112, Gilhuis, J. C., a.w., p.p. 158-201, Beyerhaus, P., Die Selbständigkelt der jungen Kirchen als missionarisches Problem, Wuppertal-Barmen, 1956, Dürr, J., Sendende und Werdende Kirche in der Missionstheologie Gustav Warmecks, Bern, 1946.

41. Vgl. die literatuur onder 40 en die volgende: W. Andersen, Towards a Theology of Mission.

H. Kraemer, The Christian Message in a non-Christian World.

42. Dür, J., a.w., p.p. 160-164, 227-244.

43. Venn, H., het as sendingdoel gestel selfonderhoudende, selfregerende cn selfuitbreidende kerke. Eers as hierdie doeleindes bereik is, is 'n kcrk selfstandig. Vgl die beskrywing en kritiese beoordeling van hierdie metode in Beyerhaus P., a.w., p.p. 31-44, 123-162.

44. Warneck. G., Evangelische Missionslehre, 5 dele, 1892-1903. Dit was die protestantse missiologiese standaardwerk en vademecum tot ongeveer 1940 en is nou nog van groot waarde.

45. de Klerk, P. J. S., Kerk en Sending in S.A., Amsterdam 1923, p.p. 65-94,

46. Neill, S., The Unfinished Task, p.p. 156-160. idem, Creative Tension, p.p. 81-112 Freytag, W., Die Neue Stunde der Weltmission. Stuttgart, 1952, p.p. 10-13, 16.

47. Andersen, W., p.p. 9-14. Neill, S., The Unfinished Task, p.p. 136-140.

48. Beyerhaus, P., a.w., p.p. 17-19.

Andersen, W., p.p. 13-14.

Gilhuis, J. C., p.p. 159-160

49. Myklebust, O. G., Integration or Independence?, p. 332.

Andersen, p. 21, Beyerhaus, p. 18,

J. v, d. Berg, Constrained by Jesus' Love, Kampen 1956, p. 203.

50. Barth, K. K.D.I,' p.p. 2, 14, K.D.I. ${ }^{2}$, p. 234, idem, Credo, Zolikon, 1939, p. 124 Andersen, p. 21.

Oor die sendingbegrip van $\mathbf{K}$. Barth vgl, verder sy Die Theologie und dic Mission in der Gegenwart in Zwichen den Zeiten, 10de jrg., no. 3, 1932 cn I. P. C. van 't Hoff, Het Zendingsbegrip van Karl Barth, Hoenderloo, 1946, asook K. Barth Auslegung v. Matt, 28: 16-20, Basel, 1945.

51. Hartenstein, K., in Mission Zwischen Gestern und Morken. Stuttgart, 1952, p.p. 5153, verder vgl. o.a. Kraemer. H., The Christian Message in a non-Christian World, 
p.p. 414-423. Durr, J. a.w., Andersen, W. a.w.

Holsten, Das Kerygma und der Mensch, München, 1953, p. 120 e.v., Kantonin, T. A., The Theology of Evangelism3', Philadelphia, 1954, p.p. 93-94.

Newbigin, L., One Body, One Gospel, One World, Londen, 1958, p. 17 e.v., Vicedom, G. F., Missio Del. München, 1958, p. 67 e.v., N. Goodall e.a., Missions under the Cross.

52. Dürr, J., a.w.

53. Idem, p. 195.

54. Idem, p.p. 243-244.

55. Andersen, в.w., p.p. $20-22,26,31,34-36$.

56. The Missionary Obligation of the Church, verslag van Willingenkonferensie, Londen, 1953, p. 3-4.

57. The Missionary Obligation of the Church, p. 3 .

58. In hierdie opsig het die jong kerke die eintlike probleem baie beter as die ou kerke raak gesien. Hulle klagte was en is vandag tot 'n groot mate nog dat, terwyl hulle self kerke is en as kerke, en nie as genootskappe nie, self sending doen, hulle sonder enige kerkdlke verbend is met die ou of ander kerke as korke en dat hulle alleen maar te doen kry met sendingrade, sendelinge. sendingvereniginge en kommissies. Hulle wil nie die band met die ou kerke afsny nie, maar wil as kerke erken word en in kerklike verband met dle ou kerke wees, vgl. S. Neill Creative Tension, p. 96. W. Freytag, Die Neue stunde der Weltmission, p.p. 12-16, vgl. ook Missionary Obligation, p. 40: We are convinced that missionary work should be done through the church. We should cease to speak of "missions and churches" and avoid this dichotomy not only in our thinking but also In our action. We should now speak about the mission of the church. (Verklaring van die verteenwoordigers van die jong kerke op die konferensie).

59. J. C. Hoekendijk veral het kart voor die sitting van die konferensie sterk gereageer teen enige vorm van ekklesiosentrisme; vgl. sy artlkel in International Review of Missions, Julle 1952, p.p. 324-336, Volgens W. Andersen het die konferensie mede as gevolg van hlerdie reaksie nie tot sterk omlynde besluite gekom nie: W. Andersen, p.p. 36-40.

60. The Missionary Obligation of the Church, p. 2: „The missionary movement of which we are a part has its source in the Triune God Himself. Out of the depth of His love for us, the Father has sent forth His own beloved Son to reconcile all things, to Himself, that we and all men might, through the Spirit, be made one in Him with the Father in that perfect love which is the very nature of God".

Ook K. Barth stel die oorsprong van die sending trinitaries, vgl. sy Die theologie unil die Mission in der Gegenwart, in Zwischen den Zeiten, 10de jrg. no. 3, 1932, p. 204. Dit is dan ook byna die algemene opvatting in missiologiese werke van betekenis vandag. Andersen is van gedagte dat met hierdie uitgangspunt die weg gevind kan word vir die oplossing van die nog onopgeloste sendingprobleme: Andersen, W., p. 56.

A. Kuyper het reeds in 1890 sodanige trinitarlese fundering op die "ZendingCongres to Amsterdam", in die volgende woorde gestel: "Alle zending vloeit voort uit de souvereinitelt Gods; berust op de schepping van den mensch nasr Gods beeld, is noodzakelljk om der zonde wil en ligt gegrond in de belljdenls dat de Hellige Geest niet alleen van den Vader, maar ook van den Zoon uitgaat". Acta, Zending-Oongrea, Amsterdam, 1880, p. 2.

61. Hartensteln, $K$. In Zwischen Gestern und Morgen, p. 54 e.v. 
62. Renewal and Advance: Christian Witness in a Revolutionary World. (verslag van die Whitby-sendingkonferensie), Londen, 1948 ed. C. W. Ransom, p. 173 e.v.

63. Beyerhaus, P., a.w., p. 306. vgl. The Missionary Obligation of the Church, p. 20-21 ..Partnership is not enough, for it implies the existence of independent groups which may or may not choose to work together".

64. The Missionary Obligation of the Church, p. 3.

65. Beyerhaus, P., p. 306

66. Idem.

67. Vgl. J. v. d. Berg, Constrained by Jesus' Love, p. 185: „In our present day, we have come to a now recognition of the value of the idea of the Church in the context of missionary thinking, while at the same time the eschatological factor, loosened from millenarian speculations is once more going to play a very important part. Is it possible that we are returning to an integration of the ekklesia and baseliea in a missionary theology that is church-centred and eschatologically-minded all in one?"'

68. In bogenoemde formuleringe van die trinitariese oorsprong van die sending word in die reèl uitgegaan van die handele van die Triniteit in die geskicdenis By Barth verkry die christologiese die aksent bo die trinitariese en word dit christomonisties.

69. Kuyper, A., Uit het Woord, VI, Amsterdam 1886, p.p. 32-41.

70. Idem. Vir Voetius is die grondslag van die sending in die ewige besluit of wil van God en in die beloftes en die bevel van God. Die sending is as middel tot die doel opgeneem in die ewige besluit van God. Sien van Andel, H. A., De ZendingsIeer van Gisbertius Voetius, Kampen 1912, p. 60-63.

71. Raadpleeg: K, Dijk, Van Eeuwig verkoren, Delft 1952, 1952, p.p. 37-58, 78-80; idem, Om 't Eeuwig Welbehugen. Amsterdam 1924; p.p. 168-264, Bavinck, H. Gereforneerie Dogmatiek II, Kampen 1908, p.p. 347-425.

72. Bavinck, H., p.p. 384-387.

73. Dijk, K., Van Eeuwig Verkoren, p.p. 87-88.

74. Idem, p.p. 113-115.

75. Berkouwer, G. C., Do Verkieging (hods, Kampen, 1955, p.p. 186, 194-197, Dijk, K a.w., p. 88

76. Dijk, K., a.w., p.p. $88-90$.

Berkouwer, G. C., p.p. 153-181.

Bavinck, H. p. 421.

77. Dijk, K., a.w., p. 114. vgl. Dordtse Leerreëls, I, 7; H. Kat. Sondag 21, Nedl. Geloofsbelydenis, art. 16. Kuyper, A., a.w., p. 36

78. Dijk, K., a.w., p.p. 82, 107. Ridderbos, H. N., De Konnst van het Koninkrijk, Kampen, 1950, p.p. 183-188.

79. Dijk, K., a.w., p.p. 108, 125 Calvyn Institusio III, 21, Durltse Inerreily I', 15, 16; Nedl, Celoofshelyilenis, arl. 16.

80. Berkouwer, G. C., p.p. 153-188. Dijk, K., a.w., p.p. 111-117.

81. Berkouwer, G. C., p.p. 168-173.

Dijk, K., a.w., p.p. 86-88, 111-117.

Bavinck, H., p.p. $423-425$.

82. Kuyper, A., Uit het Woord VI, p.p. 32-41.

Dictaten Dogmatiek, Kampen, 1910;, Locus de Ecclesia, p. 88 e.v. 
83. Dijk, K., a.w., p.p. 89-90.

84. Kuyper, A., a.w., p.p. 102 e.v.

85. Idem, Uit het Woord VI, p. 39

86. Nedl. Geloofsbelydenis, art, 27, H. Kat., S.21, vr. 54

87. Kuyper, A., Locus de Ecclesia, p.p. 96-101.

88. Dijk, K., Van Eeuwig Verkoren, p. 86

89. Kuyper, A., Acta Zending-Congres, p.p. 2-4.

Vicedom, G. F., Missio Dei, München, 1958, p.p. 45, 63-65

90. Berkouwer, p.p. 383-394.

Rowley, Vriezen en van Dijk erken net 'n verkiesing tot diens en nie tot saligheid nie. I. v. Dijk, De leer der verkiezing in het Nieuw Testument. Gezam. geschriften, I, 1917, p.p. 232, 262. Th, C. Vriezen Die Erwihlung Israels nach dem A.T., 1953, p. 34, Rowley H. H., The Biblical Doctrine of Election, 1953', p.p. 42, 44, 62, 68, 170, 172,174 The Missionary Message of the Old Testament, Londen, 1955', p. 57 e.v.

91. Berkouwer, G. C., a.w., p.p. 392-393. Kuyper, A, Uit het Woord II, Amsterdam, 1875, p.p. 258-266.

92. Kuyper, A., Uit het Woord VI, p.p. 15, 32 e.v. idem II, 263.

Dijk, K., a.w. p. 87: vgl. Th. C. Vriezen, De Zending in het O. Test. in De. Heerbaan, Mei-Junie, 1954, p. 110.

93. Berkouwer, G. C., Het Werk van Christus, Kampen, 1953, p. 65 e.v. Kuyper, A. Enoyclopaedie der Heilige Godgeleerdheid II, p. 58, e.v., III, p. 471 e.v. Bavinck, H., a.w. II, 423, III 400-401.

94. Ridderbos, H. N., Zending in het $\mathbf{N}$. Test. in De Heerbaan, Julie-Aug. 1954, p.p. 134-141.

Bavinck, J. H., Inlelding in de Zendingawetenschap, Kampen, 1954, p. 73.

95. Ridderbos, H. N., De Apostollelteit van de Kerk volgens het $\mathbf{N}$. Test. in De Apostolische Kerk, Kampen, 1954, p. 77.

96. Idem, p. 40 e.v. Ridderbos, H. N., De Komst van het Koninkrijk, Kampen, 1950, p. 321 e.v.

97. Idem, p.p. 320-326.

98. Idem, De Apostoliciteit ens., p.p. 96 e.v., 46 e.v., 77. Idem, p.p. 46-49.

Idem, De Komst ens., p.p. 320-326

99. Idem, p.p. 308-323.

Idem, De Apostoliciteit ens., p. 42 e.v.

Ridderbos, H. N., in De Hexerbann, a.w., p.p. 139-141.

Oor die verband van die apostoliese amp en die kerklike diakonia vgl. Ridderbos, De Komst, ens. p. 308 e.v. en in De Apostolische Kerk, p. 88, e.v.

100. Boer, H. R., Pentecont and the Missionary Witness of the Chureh, Franeker, 1955 , p. 92 e.v.

Kraemer, H., A Theology of thp Laity, Londen, 1958, p.p. 132-133,

Dillistone, F. W., The Dispensation of the Apirit in Missions under the Cross, p. 84.

101. Bavinck, J. H, a.w, p.p. 65-66,

Vicedom, G. F., Missio Dei, p.p. 12-16.

Bijbelse Grondslagen (verslag van die studiekommissie van die Nedl. Sendingraad) in de Heerbaan, Aug., 1951, p. 207.

102. Ridderbos, $H, N_{\text {, }}$ in De Herbaan, Julie-Aug., 1954, p. 140. 
103. Idem, p.p. 140-141, in De Apostolische Kerk, a.w., p.p. 88 e.v., idem De Komst ens p.p. 308-318.

104. Elke lidmaat het 'n sendingroeping maar nie sonder verband met dic gemeente nie. Vgl. Zielhuis, L., Het begrip ,Zendende Kerk" In het $\mathbf{N}$. Test., in De Heerbaan, Jan.-Feb. 1955, p.p. 16-18. Die kerk van die Here is uitverkies as 'n volk, 'n koninkryk van priesters om te getuig (1 Pet. 2:9). Sending is in die eerste plek die taak van die hele kerk. Daarom bevredig Bergema se definisie dat sending die roeping is "van die kerk als geheel en van ieder gelovige afzonderlijk" nie heeltemal nie: Bergema, H., Universaliteit en Eigen Kring in de Missiologia, Kampen, 1956, p. 9.

In die meer resente missiologiese en evangelisasie-lektuur word baie nadruk gelê op die sending- en evangelisasieroeping van die hele gemeente, vgl. $\mathbf{H}$. Kraemer, A Theology of the Laity, p. 48 e.v., p. 158 e.v. M. A. C. Warren, The Christian Mission, Londen, 1954^, p. 63 e.v. Bavinck, J. H. Inleiding in de Zendingswetenschap, p. 75. Kantonin, T. A., a.w., p.p. 95-98. Walker, A., The Whole Gospel for the Whole World, p.p. 86-89. Hartenstein, $K$., in Die neue Stunde der Weltmission, p. 28.

105. Sendingorde van die Geref. Kerk in S.A., art. 3 , Acta Generale Sinode van de Getref. Kerken in Nedl., 1896, p. 68 de Klerk, P. J. S., Kerk en Sending in S.A., p. 121 e.v., 150-155

106. Zielhuis, L., a.w., p. 18 e.v. Sendingorde van die Geref. Kerk in S.A, art, 1 en 2.

In byna alle nie-Geref. kerke is die plasslike gemeente nie die sendende orgaan nie.

107. Die kerklike karakter van die sending word nie soos $\mathbf{S}$. Neill in Creative Tension p.p. 92-93 bepleit daardeur verseker dat die sendingleraar 'n leraar word van die jong gemeente nie. As sendeling is hy iemand wat gestuur word deur die sendende kerke en hy beklee dus geen amp in die jong kerk nie. Die praktyk in die Ned. Geref. Kerk dat die missionêre leraar 'n leraar kan weeg van die jong gemeente en dat hy sitting neem op die sinode van die jong gemeentes is nie in orde nie.

108. Dijk, K., De Apostolische Kerk in hanr Interne Dienst in De Apostolische Kerk, p.p. 173-174.

Van der Walt I. J. Die Pluraditeit van die Kerk, Potchefstroom, 1956, p. 79 e.v.

109. Neill, S., Creative Tension, p. 84 e.v.

110. Handelinge van die Algemene Sinode van die Geref. Kerk in S.A., 1958, Potchefstroom, p.p. 236, 148-249, 265-266.

Snijman, W. J., Ekumenisiteit van die Kerk by Calvyn, Die Kerkblad, 28 Okt. 1959, p.p. 8-9.

111. Ooreenkomstig die Geref, kerkreg is gemeentes verplig om op meknar toesig te hou.

112. Vgl. Beyerhaus, P., a.w., p.p. 295-296 en Nygren, A., Christ and his Church, Philadelphia, 1956, p. 99: „Jesus Christ is present in all his fulness in the local congregation; so also the local congregation represents the body of Christ in all its fulness".

113. Zielhaus, L., a.w. p. 18 e.v.

114. Neill, S., Creative Tension, p.p. 86-87.

Idem, The Unfinished Task, p.p. 202-203, 208.

115. Ned. Geref. sendinglersars word nog uitgestuur deur sinodale of ringsending- 
kommissies, maar in enkele gevalle is plaaslike gemeentes die sendende organe en dit wil voorkom of hierdie meer Geref. praktyk al meer voorgestaan word: vgl. A. B. du Preez, Die Kerkregtelike Posisie van die Sendeling in ons nuwe Sendingaksie in Op die Horison, Sept. 1959 p. 8 e.v. Volgens prof. du Preez moet 'n sendeling in die laaste geval lidmaat wees van die blanke gemeente wat naaste aan sy arbeidsveld is. Ons kan dan die ongerymdheid kry dat 'n sendeling 'n predikant van een gemeente is en 'n lidmaat van 'n andereen.

O.a. L. Newbigin in One Body, One Gospel, Ono World, Londen 1958, p. 46 e.v. en S. Neill in Creative Tension, p.p. 105-106 bepleit in sekere gevalle uitsending deur ekumeniese rade.

116. Kuyper, A., Uit het Woord, VI, p.p. 32-41.

117. Idem, p.p. 42-52.

Bavinck, H., a.w. IV, p. 349 .

Calvyn, a.w.; IV I, 2.

118. Idem IV 1,3 .

Bavinck, a.w., p. 349.

Dijk, K., in De Apostolische Kerk, p.p. 42-43.

119. Ridderbos, De Komst van het Koninkrijk, p. 824.

Jansen Schoonhoven, E. De Jonge Kerken en de Ecclesiologie in Ecclesia, ed. H. Brummelkamp e.a., 's Gravenhage, 1959, p. 212.

120. Dijk, K., a.w., p. 139. vgl. E. Schlink, Die Einheit der Kirche und die Uneinigkeit der Christen in Basileia ed. J. Hermelink en H. J. Margull, Stuttgart, 1859, p. 407: „Kirsche ist nur da, wo das apostolische Zeugnis als Grund, Richter und Norm der Kirche anerkannt wird".

121. Die kerk is nie net belydende kerk nie soos deur die apostolaatsteologie geleer word nie, want dit is die belydenis wat bely moet word; vgl. Dijk, K., De Belijalendo Kerk in De Diest der Kerk, Kampen, 1952, p. 17 e.v.

122. B. Wurth, G., De Apostolant van de Kerk" in deze Tijd, in De Apostolische Kerk, p.p. 131-133.

123. Jansen Schoonhoven, E., a.w., p.p. 203-213.

124. The Missionary Abligation of the Church, p. 40: "While unity may be desirable in the lands of the older churches, it is imperative in those of the younger churches". (Verklaring van die verteenwoordigers van die jong kerke op die Willingen-konferensie).

125. Bavinck, J. H., Onze Kerke Zendingskerk, Kampen, 1948, p. 48.

126. Mackay, J. A., The Great Commission and the Church To-day in Missions under the Cross, p. 140.

127. Uit die verband is dit duidelik dat $\mathrm{Hy}$ bid om eenheid tussen die gelowiges.

128. Daar is ' $n$ eenheid van alle gelowiges in Christus maar dit is nige 'n kenmerk van die ware kerk nie, en die aanvoeling van 'n eenheidsband in Christus wat die waarheid is, kan nie soos $H$. Berkhof in sy Gods ene Kerk en onze vele Kerken, Nijkerk, p. 51 e.v., dit stel sonder meer 'n eenheidsbasis wees vir geinstitueerde kerke nie. Vir kerklike eenheid moet daar wees die drie kenmerke vir 'n ware kerk nl. die suiwere bediening van die Woord van God, die suiwere bediening van die sakramente en die handhawing van die kerklike tug (art. 29 Nedl. Geloofsbelydenis). vgl. J. H. Bavinck, Apostoliciteit on Katholiciteit in De Apostolische Kerk, p, 236 e.v.

129. Vgl. Acta van die Geref. Ekumeniese Sinode van Edinburgh, 1953, p. 17 v., 23 v.) Bavinck, J. H., a.w., p. 226 e.v. 
130. Bavinck, J. H., a.w., p. 233-235.

131. Dijk, K., De Belijdende Kerk, a.w., p. 17 e.v.

132. Boer, H. R., That my House may be Fllled, Grand Rapids, 1957, p.p. 41-52, 85-91.

133. Vgl. B. Wurth, G., Heroriëntering, p.p. 26-41.

134. Kraemer, H., Kerk en Zending, 's Gravenhage, 1936, p.p. 7, 12, 24, A Theology of the Laity, p.p. 130-131,

135. Barth, K, K.D.II 2, p. 129 e.v.

136. Kuyper, A., Uit het Woord, VI, p.p. 13-22

137. Idem, p.p. 15, 16, 24.

138. Matt. 28:19, Kuyper, A., a.w., p. 14,

139. B. Wurth, G., a.w., p. 49.

140. Hoekendijk, J. C., The Church in Mlssionary Thinking in International Review of Missions, Julie 1952, p.p. 324-336.

Hartenstein, $K$, in Zwischen Gestern und Morgen, p.p. 66-68, 70.

141. v. d. Berg, J., a.w., p.p. 204-206.

142. Bijbelse Grondslagen van de Zending in De Heerbaun, a.w., p. 200.

143. Vgl. H. A. van Andel, a.w., p. 143.

144. Bavinck, J. H., Inleiding in de Zendingswetenschip, p.p. 157-158.

145. Ridderbos, H. N., De Komst van het Koninkrijk, p.p. 296-308.

146. Ridderbos, H. N., De Apostoliciteit van de Kerk volgens het N.T., a.w., p. 69.

147. Idem, a.w., p.p. 70-73.

148. Idem, De Komst van het Koninkrijk, p. 13

149. Andersen. W., a.w., p. 58.

150. Volgcns Bergema regverdig dic ontkerstening van die sg. Christelike Wêreld al meer die opname van die evangelistiek in die missiologie in ruimer sin (Bergema, H., p. 13). Daar word selfs voorgestel dat die jong kerke ook sendingwerk onder die ontkerstende blankes in Europa moet doen, vgl. Newbigin, L., One Body, One Ciospel, One World, p.p. 30, 37.

Sendingobjekte is o.i. alleen ongelowiges met 'n tradisionelc etniese ongeloofsagtergrond.

A. A. van Ruler wil tereg die onderskeid tussen evangelisasic en sending prinsipieel handharf, Theologie van het Apostolaat, Nijloerk, p.p. 43-46.

151. Ridderbos, H., N., De Komst van het Koninkrijk, Hoekendijk, J. C., Kerk en Volk in do Duitse Zendingswetenschap, p. 223 e.v., M. A. C. Warren, The Truth of Vision, Londen, 1948. E. Jansen Schoonhoven, De Hecrbaan. Aug. 1950, p. 197 e.v., Mei 1955, O. Cullmann, Christus und die Zeit, Zollikon-Zürich, 1948-. A. A. van Ruler, Theolorie van het Apostolaat, p. 14 e.v. A. Schweitzer, Gesehichte der Leben - desu - Forschung, p.p. 390-433. K. K. Barth, Auslegung van Matt. 28:16-20, Basel, 1945. Sicn verder die literatuur aangegec deur Ridderbos, a.w., p.p. 12-23, 373-383.

152. Bergema, H., a.w., p. 14

153. Idem, p.p. 13-14.

154. v. d. Berg, J., a.w., p.p. 207-208.

155. Riddarbos, H., a.w., p.p. 444-447.

156. Jansen Schoonhoven. E., Apostolate en Fischutologic in De Heprlaan, Mei-Junic, 1955 , p. 89.

157. Holsten, W. Das Kerygnı und der Menseh, München, 1953, p. 135 e.v. Holsten is egter in sy eskatologle sterk deur Bultmann be ïnvloed; vgl. E. Jansen Schoonhoven, Zendingswetenschappelijke Nieuwlouw in De Iecrban, Julie 1958, 
p. 152 e.v.

158. Vgl, o.a. Holsten, W, 135 e.v., K. Burth K.D. IV 1. p.p. 819-811. Bavinck, J. H. Inleiding in de Zendingswotenschap, p.p. 69-70. id., Fn voort Wentelen de Feuwen, Kampen, 1950 (?), p.p. 117-121, Bocr, H. R., Pentecost and the Missionary Witness of the Church, p.p. 143, 146. O. Cullmann, Christus und die Zeit, p. 130 c.v. E. Jansen Schoonhoven Toekomstverwaehting en Zending in De Heerbaan, Aug. 1950 p. $197 e_{1} v_{,}$id. Apostolast en Kschatologie in De Hecrbasn, Mei 1955, p. 89 c.v. A. A. van Ruler, Theologie van het Apostolant, p. 14 c.v., J. v. d. Berg. a.w., p. 180 e.v., Hartenstein in Zuischen Cestern und Morken, p.p. 67-68. Ridderbos, H. N. De Komst van het Koninkrijk, p. 441.

159. Cullmann, p. 75 e.v.

Cullmann hou egter te min rekening met die oriëntering vanuit die cskaton, vgl, Ridderbos, H. N., De Komst van het Koninkrijk, p.p. 394-397.

Warren, M. A. C., The Truth of Vision, p. 60 e.v.

160. Ridderbos, a.w., p.p. 391-395, 440-441.

161 Cullmann, p.p. 138-153.

Blauw, J., Goden en Mensen, p. 57.

Koker, J., Het Oude Test. en de Zending, in De Heerbaan, Mei-Junie, 1953,

Hoekendijk, J. C., Kerk en Volk in de Duitse Zendingswetenschaj, p.p. 244-225.

162. B. Wurth, G., in De Apostolisehe Kerk, p.p. 122- 123.

Jansen Schoonhoven, E., Apostolaat en Eschatologie, a.w., p. 98 vgl. Cullmanı, p.p. 138-153. Hoekendijk, J. C., a.w., p.p. 224-227.

163. Idem, p. 224. B. Wurth, G., a.w., p. 122. Jansen Sehoonhoven, E., a.w. p. 98.

164: Ridderbos, De Komst van het Koninkryk, p.p. 391-395, 440-441.

165. Idem, p.p. 68, 392, 441-443

166. Culimann, p.p. 75,199 ; vgl, v, Swigchem De Bijhelse: (iedachte over het Koninkryk Godw i.v.m. de Perspectieven van het Apostolaat in Vox Theologica, Julie 1959, p.p. 175-176.

167. Ridderbos, a.w., p. 127.

168. Berkhoff Christus de Zin der Cieschiedenis, Nijkerk, 1958, p. 65.

169. Ridderbos, a.w., p. 68 .

170. Cullmann, p.p. 143-146; Berkhoff, a.w., p. 75 e.v.; Blauw, J., De Andere Werold, Kampen, 1950, p.p. 72-74.

171. Hoekendijk, J. C., a.w., p. 223.

172. Ridderbos, Zending In het Nieuw Testament, a.w., p. 137.

173. Vgl. G. C. Berkouwer, Vragen der Eschutologie in (ieref, Weekhlad, 15de jrg., no's. 28-33.

174. Ridderbos, H. N., in De Apostolisehe Kerk, a.w., p. 138.

175. Van Swigchem, D., Het Missionair Karakter van de Christelijke gemeente, Kampen, 1955, p.p. 235-236, Ridderbos, H. N., a.w., p.p. 141-142.

176. B. Wurth, G., Evangelieboodskap en Wêreldkrisis, Pretoria, 1959, p.p. 12-17. Blauw, J., De Andere Wereld, p. 73, Ridderbos, De Komst van het Koninkrijk, p. 130 e.v. Warren, M. A. C., The Christian Mission and the Cross, in Missions under the Cross, p. 33.

177. Van Swigehem, D., in Vox Theologica, a.w., p.p. 175-176.

178. Van Swigchem, D., Het Missionair Karakter van de Christelijke Gencente, p. 229. Blauw, J., De Andere Wereld. Chandran, J. R., The Christtian Mission and the Judgment of History in Missions under the Cross, p. 100.

179. Van Swigchem, D., a.w., p.p. 233, 235 e.v. V.d. Berg, J, a.w., p. 208. Warren, M. A. C., The Truth of Vlaion, p. 149 e.v. 
Blauw, J., Goden en Mensen, p. 164.

180. Torrance, T. F., aangehaal deur J. v.d. Berg. a.w., p. 204.

181. Ridderbos, H. N., Zending in het N. Test., k.w., p.p. 141-142

Vgl. J. H. Bavinck, Inleiding in de Zendingswetenschap, p.p. 59-62, 78-82.

182. Blauw, J., De Andere Wereld, p. 75.

183. Walker, A., The Whole Gospel for the Whole World, Edinburgh, 1958, p. 21.

184. Vgl. Berkhof, a.w., p. 85 e.v., B. Wurth, G., e.w., p. 14 e.v.

Vgl. A. Kuyper, De Gemeene Gratie, I, Amsterdam, 1902, p.p. 425-454.

185. Walker, A., a.w., p.p. 21-22.

186. Warren, M. A. C., a.w., p. 149.

187. Bavinck, J. H., Onze Kerk Zendingskerk, p.p. 32-34.

188. Freytag, W., Changes in the Patterns of Western Missions in International Review of Misslons, April 1958, p. 169-170.

189. In Christus de ZIn der Geschiedenis van Berkhof word die einde te vecl gesien as die voleinding van ' $n$ kontinue ontwikkeling.

190. Van Swigchem, D., a.w., p. 235.

191. Idem, p.p. 237-238, vgl. A. Kuyper, Ult het Woord, VI, p. 29.

192. Van Swigchem, D., a.w., p. 248.

193. Idem, p.p. 249, 251.

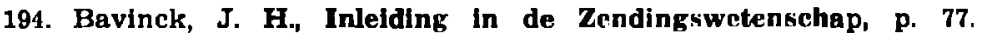

195. Van Swigchem, a.w., p. 251.

196. Boer, H. R., a.w., p. 113.

197. Bavinck, J. H., Religieus Beref en Chr. Geloof, p.p. 190-191, idem. Inleiding. p. 139 e.v.

198. Andersen, $W_{.,}$a.w., p.p. 59-61.

199. Idem, p. 61, vgl, Idem, p.p. 59-61, en Blauw Goden en Mensen, p.p. 167-168.

200. Bavinck, J. H., En Voort Wentelen de Eeuwen, Wageningen, 1950(?), p.p. 127-129. Berkhot, H., a.w., p.p. 78-91, 105-113.

201. Freytag, $W$., Die neue Stunde der Weltmission, p.6.

Kraemer, H., The Christian Message in a non-Christian World, p.p 1-30.

Idem, Communication of the Christian Faith, p. 89 e.v.

Bavinck, J. H., a.w., p.p. 187-188.

202. Freytag, W., Changes in the Patterns of Wes:ern Missions, p. 164

V. d. Post, L., Dark Eye in Africe, 1955, p. 59.

Forman, C. W., A Faith for the Nations, Philadelphla, 1958, p.p. 72-86.

203. Freytag, W., a.w., p. 164.

204. Idem, Kirchen in Neuen Asien, Stuttgart, 1958, p.p. 10-11.

205. Bergema, H., Het Nieuwe Azfë, in Pioniers van het Nieuwe Azlë, deur Bergems, H., e.a., Franeker, 1959, p.p. 37-66. Vgl. verder G. F. Vicedom, Dle Weltreliglonen Im Angriff auf das Christentum; München, 1956, Dle Mission der Weltreligionen, München, 1958, S. Kulandran, Resurgent Rellgions, Londen 1957, H. du Plessis. Het die Christendom gefaaly Potchefstroom, 1960.

206. Vgl. J. Blauw De Andere Wereld, Okke Jager, Interview met de Tijdgeest, Kampen, 195B, p.p. 19-22.

207. B. Wurth, G., Evangelleboodskap en Wereldkrisis, p.p. 57-68.

Berkhot, H., a.w., p.p. 81-84.

208. B. Wurth, G., a.w., p.p. 9-10.

Bavinck, J. H., Inleiding in de Zendingswetenschap, p. 77.

209. Kraemer, H., A. Theology of the Laity, p.p. 185-188. 
B. Wurth, G., a.w., p.p. 6, 16, 17 .

210. Idem, p.p. 16-17.

Bavinck, J. H., a.w., p. 227 e.v.

211. B. Wurth, G., a.w., p.p. 16-17.

212. Kuyper, A., Encyclopaedie der Heilige Godgeleerdheld II, p.p. 273-277.

213. Dijk, K., De Dienst der Kerk, p. 42 e.v.

214. Kuyper, A., a.w., III, p. 246-249.

215. Dijk, K., a.w., p. 70 e.v.

216. V.d. Berg, J., a.w., p. 188.

217. Vgl. Berkouwer, G. C., wat in sy reeks Dogmatische studiën telkens hierop attenteer.

218. V. d. Berg, J., a.w., p. 2.

219. Idem, p.p. 214-215.

220. Myhlebust, O. G., Integration or Independence? in Basileia, p.p. 331-332. Neill, S., Creative Tension, p.p. 111-112.

221. Andersen, W., a.w., p. 59 e.v. Myklebust, O. G., a.w., p.p. 337-338.

Blauw, J., Goden en Mensen, p.p. 167-168.

222. Myhlebust, O. G., The Study of Missions in Theological Education II, p. 289.

223. Bavinck, J. H., a.w., p. 15.

224. Idem, p.p. 10-13.

225. Bergema, H., p.p. 20, 22.

226. Kuyper, A., a.w., III, p. 481 e.v.

Bevinck, J. H., a.w., p.p. 13-16.

227. Kuyper, A., a.w., p. 359 e.v.

228. Bavinck, J. H., a.w., p. 233.

229. Idem, p. 17.

230. Bergema, H., a.w., p.p. 16-17.

231. vg. o.a., H. Kraemer, De Plasts van de Godsdlenstwetenschap en Godsdienstfenomenologie in de Theologische Facultelt, Nijkerk, 1950, en W. Holsten, Das Kerygma und der Mensch, p. 43 e.v.

232. Kuyper, A., a.w., p. 563 e.v.

Bavinck, J. H., a.w., p. 234 e.v.

233. Bergema, H., a.w., p.p. 20-21.

234. Idem, p. 21. 